\title{
Research priorities for seabirds: improving conservation and management in the 21 st century
}

\author{
R. Lewison 1,* , D. Oro ${ }^{2}$, B. J. Godley ${ }^{3}$, L. Underhill ${ }^{4}$, S. Bearhop ${ }^{3}$, R. P. Wilson ${ }^{5}$, D. Ainley, \\ J. M. Arcos, P. D. Boersma, P. G. Borboroglu, T. Boulinier, M. Frederiksen, \\ M. Genovart, J. González-Solís, J. A. Green, D. Grémillet, K. C. Hamer, G. M. Hilton, \\ K. D. Hyrenbach, A. Martínez-Abraín, W. A. Montevecchi, R. A. Phillips, P. G. Ryan, \\ P. Sagar, W. J. Sydeman, S. Wanless, Y. Watanuki, H. Weimerskirch, P. Yorio
}

${ }^{1}$ Institute of Ecological Monitoring and Management, San Diego State University, San Diego, California 92182-4614, USA

${ }^{2}$ CSIC UIB, Institut Mediterrani Estudis Avancats IMEDEA, Esporles 07190, Mallorca, Spain

${ }^{3}$ Centre for Ecology \& Conservation, University of Exeter, Cornwall Campus, Penryn, Cornwall TR10 9EZ, UK

${ }^{4}$ Department of Zoology, Animal Demography Unit, University of Cape Town, 7701 Rondebosch, South Africa ${ }^{5}$ Institute of Environmental Sustainability, Swansea University, Institute of Environmental Sustainability, Singleton Park, Swansea SA2 8PP, UK

\begin{abstract}
Seabirds are facing a growing number of threats in both terrestrial and marine habitats, and many populations have experienced dramatic changes over past decades. Years of seabird research have improved our understanding of seabird populations and provided a broader understanding of marine ecological processes. In an effort to encourage future research and guide seabird conservation science, seabird researchers from 9 nations identified the 20 highest priority research questions and organized these into 6 general categories: (1) population dynamics, (2) spatial ecology, (3) tropho-dynamics, (4) fisheries interactions, (5) response to global change, and (6) management of anthropogenic impacts (focusing on invasive species, contaminants and protected areas). For each category, we provide an assessment of the current approaches, challenges and future directions. While this is not an exhaustive list of all research needed to address the myriad conservation challenges seabirds face, the results of this effort represent an important synthesis of current expert opinion across sub-disciplines within seabird ecology. As this synthesis highlights, research, in conjunction with direct management, education, and community engagement, can play an important role in facilitating the conservation and management of seabird populations and of the ocean ecosystems on which they and we depend.
\end{abstract}

KEY WORDS: Seabird conservation · Research priorities $\cdot$ Population dynamics $\cdot$ Threats $\cdot$ Fisheries interactions $\cdot$ Tropho-dynamics $\cdot$ Climate change $\cdot$ Spatial ecology

Resale or republication not permitted without written consent of the publisher

\section{INTRODUCTION}

Seabirds have been the focus of human observation for millennia and of scientific study and observation for centuries (Charles Darwin, Tierra del Fuego, Jan 13, 1833: 'We were heavily labouring, it was curious to see how the Albatross with its widely expanded wings, glided right up the wind'. http://darwin- online.org.uk/). In more recent years, there has been strong evidence of steady, and for some species dramatic, changes in seabird populations in many areas (Schreiber \& Burger 2002, Butchart et al. 2004). While for some populations there has been rapid population growth (e.g. northern fulmars Fulmarus glacialis in the North Sea in the 1980s), many other seabird species have demonstrated marked declines. Reported 
seabird declines follow global patterns of biodiversity loss, with between 10 and $50 \%$ of species in wellstudied higher taxonomic groups currently threatened with extinction (MEA 2005, Schipper et al. 2008). Seabirds are long-lived organisms that exhibit high adult survival and a progressive recruitment to the breeding population as immature individuals near sexual maturity (Schreiber \& Burger 2002). They breed mostly in social structures (i.e. colonies, see Jovani et al. 2008) commonly in coastal areas, and they tend to be philopatric, especially once recruited to a specific colony (Milot et al. 2008).

Many factors have been implicated in documented changes in seabird populations, e.g. direct harvest, incidental mortality in fisheries, fisheries closures and changes in fishing practice, pollution, non-native and invasive alien species, and changes in prey availability as a consequence of fisheries or changing ocean conditions. It is estimated that one quarter of marine fish stocks on which seabirds depend are overexploited by fisheries (Hilborn et al. 2003, Roberts et al. 2007). Although fisheries serve as a pervasive and global driver of change in marine ecosystems, the effects of fisheries on seabirds are not clearly understood (Watermeyer et al. 2008a,b). Coincident with these factors, seabirds also exhibit considerable variability in behavior, ecology, life history and demography (Garthe et al 1996, Hamer et al. 2002, Weimerskirch 2002) and respond to short-term and long-term changes in ocean conditions (Aebischer et al. 1990, Sydeman et al. 2009). Thus, one of the central challenges to seabird research has been untangling the differential impacts of environmental variation and anthropogenic activities on seabird population dynamics.

Seabirds are important indicators of the status and structure of marine ecosystems, because as widespread organisms, they inhabit all ocean systems (from inshore to pelagic, polar to tropical) and are relatively easy to monitor at large spatio-temporal scales compared to other upper-trophic marine organisms, (Furness \& Camphuysen 1997, Durant et al. 2009). By nature of their reliance on the marine environment for food, and on terrestrial habitats for breeding, research on seabirds provides a 'window' into both marine and terrestrial systems (Grémillet \& Charmantier 2010).

While ongoing research informs much of seabird management strategies, identifying the most critical knowledge gaps in seabird ecology that limit effective seabird management and conservation is a timely and important exercise. Following the initiatives of Sutherland et al. $(2006,2009)$ and Hamann et al. (2010) that identified key ecological questions relevant to biodiversity conservation and policy, a group of researchers working in seabird biology, ecology and conservation compiled a list of 20 high-priority research questions. The present paper reflects the expertise of a group of seabird researchers with a broad range of backgrounds, and details the top priority conservation-related research questions for seabirds. Through this process, we aim to strengthen the role of seabird research in facilitating and improving the conservation status of seabirds. Although this exercise focused particularly on seabirds, the threats and challenges to seabird conservation are relevant to many other marine top predators, such as sharks, tunas, marine mammals and turtles (Heithaus et al. 2008).

\section{METHODS}

Using ISI Web of Science, the first 6 authors identified 180 candidate participants based on the number of publications between 2006 to 2009 for '(seabird or marine bird) and conservation' (accessed 10 April 2009). From this list we selected 35 participants (30 male, 5 female) who represented the most comprehensive geographic expertise across ocean basins as well as technical subject expertise. Each participant was asked to list the 10 most important 'research questions that would assist in effective seabird conservation over the next decade'. Twentynine researchers (25 male, 4 female) from 9 countries responded to the questionnaire (see Supplement 2 at www.int-res.com/articles/suppl/n017p093_ supp.pdf. Responses were anonymous, with the compilations only shared with the wider group once all questions had been submitted.

The resulting 242 research questions were grouped into broad categories by the first 6 authors, who created a short-list of research questions that was shared with all participants. The list of the top 20 research priorities was developed through participant discussions, based on the number of responses, but does not reflect a relative ranking among priorities. Once the list was finalized, small groups of participants selected one of the broad research topics and worked collaboratively to develop the supporting text. All authors reviewed the entire manuscript.

\section{RESULTS}

We identified 6 broad research topics that encompassed the specific research priorities identified by 
the participants. These topics represent the fundamental elements of seabird ecology, environmental change and cumulative impacts of human activity on seabirds and their ocean ecosystem.

\section{Population dynamics}

1.1. What are the key factors that regulate seabird populations?

1.2. How prevalent and influential are demographic anomalies or cycles, e.g. breeding failures, periods of decreased survival, disease outbreaks?

1.3. How can we best quantify demographic parameters, population size, population trends and risks of extinction per species and per colony?

1.4. What is the form and importance of population structure?

1.5. How do the interactions among seabird species influence seabird populations?

2. At-sea spatial ecology

2.1. How can we address knowledge gaps in at-sea distribution?

2.2. What habitat features delineate movement corridors or residency areas and how can researchers identify these corridors and best quantify movement behavior?

3. Trophic dynamics and community roles of seabirds

3.1. What are the roles of seabirds in communities and food webs?

3.2. How can we define, identify and map key foraging areas?

3.3. How do fisheries-mediated changes in trophic structure influence seabirds?

\section{Direct effects of fisheries}

4.1. How can we obtain detailed, unbiased and accurate measures of bycatch rates?

4.2. How do we evaluate bycatch risk to different species or colonies in space and time?

4.3. What are the population-level effects of bycatch?

4.4. What are the positive and negative effects of discards in provisioning seabirds?

5. Global change and population response to environmental variability

5.1. How resilient are seabirds to climate and related environmental change?

5.2. What are the likely cascading trophic effects on seabird population from environmental change?

5.3. How do interactions at different hierarchical scales affect seabirds' responses to environmental change?

6. Managing anthropogenic impacts (invasive species, contaminants and protected areas)
6.1. What are the population-level impacts of invasive species?

6.2. What is the population-level influence of contaminants and other pollutants?

6.3. How effective are protected areas in protecting seabirds?

\section{Population dynamics}

Understanding the factors that regulate and influence populations is an essential component of seabird conservation. Demographics are key variables in assessing extinction risk for populations and species (IUCN Red List criteria, Mace et al. 2008). Demographic rates drive population trends, and accurate estimation of demographic parameters facilitates the diagnosis of environmental causes of population change (Green 1995) and provides a framework for predicting responses to management (Frederiksen et al. 2004, Wanless et al. 2009). In general, seabirds have high survival rates, low fertility and a progressive recruitment with age, with an immature phase that can last for several years. They mostly breed in colonies and are philopatric to the natal site, although dispersal (both natal and breeding) occurs. For seabirds, estimation of underlying demographic rates is particularly important because declines in breeding populations can be influenced substantially by nonbreeders and immature birds (Grimm et al. 2005, Votier et al. 2008a). The influence of non-breeders and immature birds is particularly strong when populations are density-dependent and large numbers of sexually mature birds are queuing for recruitment; these birds can rapidly integrate into the breeding population when additive mortality occurs (Tavecchia et al. 2007, Votier et al. 2008a). The capacity of nonbreeders to mask, mitigate or exacerbate the effect of ecological perturbations (both human and natural) is poorly understood because individuals cannot be easily monitored once outside the breeding site (Oro et al. 2006b).

Changes in population size influence the persistence of populations, and high levels of fluctuation, particularly in small populations, are associated with an increased probability of extinction (Engen et al 2005). Seabirds are long-lived organisms and, as such, their population dynamics are most immediately sensitive to changes in adult survival, although changes in reproductive success and juvenile survival are important over time (Weimerskirch 2002, Finkelstein et al. 2010). Annual census information on the number of nesting individuals, age at first breeding, and mean fecundity are widely available 
for many seabird populations, e.g. for the ca. 275 species of seabirds (including Sphenisciformes, Procellariformes, Pelecaniformes and some Charadriformes); information on age at first breeding is available for more than $60 \%$ of the species. However other basic demographic information, including survival of younger age classes, percentage of nonbreeding birds in the population, fecundity following mate loss, senescence, and the strength of natal and breeding site fidelity are still lacking for many seabird species. The percentage of species for which adequate data exist decreases for these parameters: ca. $20 \%$ of species have estimates of adult survival, less than $5 \%$ of species have a known recruitment curve, and fewer than $2 \%$ of seabird species have estimates of juvenile survival. These data gaps must be addressed if we are to understand seabird population response to episodic environmental events and the capacity of seabird populations to recover from human-mediated and other environmental changes.

\subsection{What are the key factors that regulate seabird populations?}

Seabird populations fluctuate as a result of complex interactions between environmental characteristics and vital rates. Vital rates (e.g. survival, fecundity, recruitment, dispersal) can also vary as a result of deterministic factors (many of them related to human activities, e.g. human-mediated invasions) and also by the effects of density-dependence, both negative (e.g. Ruiz et al. 1998, Tavecchia et al. 2007) and positive (i.e. Allee effects, Oro et al. 2006b). As such, all of these variables act as key factors regulating seabird populations. Even though many of these factors have been analyzed independently in the literature, their relative importance is poorly documented and likely changes over time. As with most species, seabird populations are directly affected by predation (Gilchrist 1999, Oro et al. 1999, Bonnaud et al. 2009), as well as by food and habitat availability. Environmental fluctuations can indirectly drive all these factors (Doherty et al. 2004, Bertram et al. 2005, Oro et al. 2010). Seabirds have evolved a life history strategy that relies on iteroparity — repeated fecundity - over a relatively long lifetime, and seabird population growth is typically most sensitive to changes that reduce adult survival. However, the importance of changes in productivity, including complete breeding failures, can impact populations as well. Recent studies have shown that breeding success and recruitment have a strong impact on fluctuations in some populations (Jenouvrier et al. 2005a,b, Ezard et al. 2006). Dispersal, undertaken by immatures and adults as natal and breeding dispersal, respectively, is also a key parameter in seabird population dynamics as it can greatly influence population growth rates and extinction risks (Spendelow et al. 1995, Inchausti \& Weimerskirch 2002, Cam et al. 2004). The metapopulation paradigm, together with the proper estimation of dispersal rates (see Section 1.4), highlights the discrete distribution of colonies in space and the vulnerability of isolated populations with limited connectivity (Cam et al. 2004, Genovart et al. 2007).

1.2. How prevalent and influential are demographic anomalies or cycles, e.g. breeding failures, periods of decreased survival, disease outbreaks?

Abiotic environmental perturbations leading to population anomalies in seabirds include long-term and short-term oceanographic shifts, such as the Northern Atlantic Oscillation (NAO, e.g. Durant et al. 2004), El Niño-Southern Oscillation (ENSO; Schreiber \& Schreiber 1984, Veit \& Montevecchi 2006), the Pacific Decadal Oscillation (PDO) (Mantua et al. 1997) or the Indian Ocean Dipole (Cai et al. 2009) changes in the Antarctic Polar Frontal Zone, and also long periods of onshore atypical winds, tsunamis and storms (Wilson 1991, Harris \& Wanless 1996, Olsson \& van der Jeugd 2002, Barbraud \& Weimerskirch 2003, Frederiksen et al. 2008, Devney et al. 2009). These events can affect multiple demographic parameters at different time scales. The most immediate response is likely to be detected in annual breeding success because, as long-lived organisms, seabirds skip breeding or abandon the nest if their survival is jeopardized (Tavecchia et al. 2007, Le Bohec et al. 2008). Adult survival, even though it is the life-history trait most buffered against environmental stochasticity, may also decrease as a result of food shortages and reduced reproductive effort (Harris \& Wanless 1996, Olsson \& van der Jeugd 2002, Sanz-Aguilar et al. 2008). Even temporally limited events, i.e. storms, can have dramatic effects on population dynamics. Harris \& Wanless (1996) estimated that a shag population, Phalacrocorax aristotelis, affected by a winter storm would take $10 \mathrm{yr}$ to recover from a population crash which took it to its lowest level in $35 \mathrm{yr}$. ENSO, a recurring multi-year regime shift, has been linked to more marked population responses, although many of the observed declines reverse when ocean conditions revert (Murphy 1923, Wilson 1991, Barbraud \& Weimerskirch 
2003). Long-term, decadal ocean trends have been linked to crashes in prey availability (Devney et al. 2009), which have resulted in reduced adult survival, a sudden drop in breeding frequency, or complete breeding failures (Montevecchi \& Myers 1995). Ocean changes triggered by large-scale oceanic phenomena such as the ENSO and the NAO have been linked to severe negative impacts on both temperate and tropical seabird populations (Schreiber \& Schreiber 1984, Bertram et al. 2005, Oro et al. 2010).

Disease outbreaks represent a biotic type of demographic anomaly. Although seabirds seem to have very competent immune systems (Esparza et al. 2004) and live in vector-poor environments, emergent infectious diseases can cause chick mortality, with apparent cyclic patterns among years, reducing population growth rates (Weimerskirch 2004). Synergistic effects between changing environmental conditions and disease should be explored further (Rolland et al. 2009), especially as little is known about factors affecting the circulation of infectious agents at different spatial and temporal scales.

1.3. How can we best quantify demographic parameters, population status and risks of extinction per species and per colony?

As discussed, for the majority of the world's seabird populations, demographic information is lacking. For both extremely large colonies, such as some Southern Ocean and northern ocean petrels) and for rare species in urgent need of conservation action, the number of individuals in a colony can lead to challenges in obtaining demographic data. There are substantial logistical obstacles to describing the demography of tropical seabirds with protracted breeding seasons (Ratcliffe et al. 2008), and with analyzing the survival and recruitment of immature birds given (often unknown) immigration and emigration patterns and population network structure, e.g. source-sinks. This results in a bias towards data collection on temperate/polar populations, and adult birds.

Recent progress in analytical approaches has led to advances despite these challenges. Distance-sampling, its extensions into capture-mark-recapture (CMR), spatial modeling designs, and other recent refinements (Marques et al. 2007, Buckland et al. 2008, Thomas et al. 2010) are improving estimations of population size and trend (Barbraud et al. 2009, Southwell \& Low 2009), and streamlining fieldwork programs (Kendall et al. 2009). The use of meta-analysis and surrogate taxa offers potential for rapid estimation of key demographic parameters in poorly studied populations (Brooke et al. 2010). Ratcliffe et al. (2008) demonstrated a promising approach, termed 'virtual seabird' modeling, to estimating population size in a tropical seabird with protracted breeding. The rapid development of data modeling techniques that extend CMR ideas into multi-state models (White et al. 2006, Converse et al. 2009, Lebreton et al. 2009) and spacestate models (Gimenez et al. 2008, Patterson et al. 2008) opens new avenues for unbiased estimation of demographic variables, including immature survival/recruitment (Jenouvrier et al. 2008, Votier et al. 2008a, Tavecchia et al. 2009). Likewise, genetic approaches relevant at the spatiotemporal scale of population demography are now being deployed to estimate immigration/emigration rates (Milot et al. 2008, Peery et al. 2008, Boessenkool et al. 2009). Genetic techniques are also being employed to census datapoor populations using a CMR approach (Lawrence et al. 2008). Finally, electronic techniques for remote, automated and passive data-gathering are rapidly developing (Wilson et al. 2002, Adams \& Flora 2009).

1.4. What is the form and importance of population structure?

Most seabird species are spatially structured in discrete, patchy breeding sites or colonies. Although the highly vagile nature of seabirds would suggest high connectivity and thus little genetic differentiation among subpopulations, other common features in seabirds, such as strong site fidelity, or historical barriers have led to substantial genetic structure in some (Abbott \& Double 2003, Dearborn et al. 2003, Friesen et al. 2006), but not all, seabird populations (Burson 1990, Avise et al. 2000, Genovart et al. 2003, McCoy et al. 2005a, Riffaut et al. 2005, van Bekkum et al. 2006, Schlosser et al. 2009). Many factors, both biotic and abiotic, may shape population structure in seabirds (Friesen et al. 2007), and it is these factors that need to be examined within and among population networks.

Despite a strong conceptual understanding of spatial structure, the importance of seabird population structure is unresolved for many populations. Population structure is influenced by differences in habitat quality between source and sink areas, which typically reflect high and low quality sites, respectively. Although seabirds assess habitat quality of breeding areas (Danchin et al. 1998), some apparent highquality areas have been shown to act as population sinks (Ainley et al. 1990). Additionally, some studies 
have shown that adjacent colonies experiencing similar environmental conditions can exhibit different demographic responses (Tavecchia et al. 2008, SanzAguilar et al. 2009). Furthermore, even with knowledge of spatial structure, colonies are often studied as a discrete unit and not as a part of a larger network. Ongoing research highlights the importance of considering the hierarchical spatial structure at which processes are occurring. Behavioral factors affecting dispersal and recruitment among colonies or sub-colonies are an important consideration, notably in relation to the natural and changing patterns of temporal variability of habitat suitability at different spatial scales (Boulinier \& Lemel 1996).

One of the central challenges to understanding population structure in seabirds is being able to differentiate movement from gene flow. Movement patterns of banded birds may reveal a species' dispersal capabilities; however, movement per se does not translate into gene flow, i.e. effective dispersal. Caution is also required when quantifying dispersal ranges using marked individuals, because the average dispersal distances can be underestimated and can be episodic (Koenig et al. 1996). Additionally, many seabirds breed in remote or inaccessible islands or cliffs so resighting data may be also biased because of limited detectability. Molecular tools facilitate the estimation of the estimation of effective dispersal rates (Dieckmann et al. 1999, Hedrick 2001).

Population structure and connectivity among colonies likely plays an important role in the viability of seabird populations. Structure and connectivity can increase overall population viability by either allowing recolonization of suitable but unoccupied colonies or re-colonizing locally extinct colonies (Levins 1970, Dieckmann et al. 1999, Hanski \& Gaggiotti 2004). However, connectivity can also synchronize local population dynamics across subpopulations, and this has been found to increase the likelihood of global extinction (Heino et al. 1997). Additionally, dispersal, once treated as a fixed trait, is now considered a flexible trait that may change with time and space depending on environmental and individual conditions (Clobert et al. 2001, Bullock et al. 2002, Hanski \& Gaggiotti 2004). Natural and human-mediated environmental shifts (e.g. habitat destruction, fisheries mortality, fishery-induced food web changes, the introduction of invasive species, climate change) may affect connectivity among colonies and thus population viability. From a conservation perspective, there is a strong need to develop predictive models that include changes in connectivity under different environmental conditions.
1.5. How do the interactions among seabird species influence seabird populations?

Many seabird species are sympatric with others, sharing breeding and foraging habitats. Potential competition among species for prey was identified several decades ago (e.g. Ashmole 1968, Cody 1973) and has since been studied in tropical, polar and temperate ecosystems (Furness \& Birkhead 1984, Furness \& Barrett 1985, Weimerskirch et al. 1986, Cairns 1987, Ballance et al. 1997, Forero et al. 2004). Typically, there is some degree of ecological segregation among seabird species even if they exploit similar prey within a common location, for example in terms of prey sizes, foraging depths (Thaxter et al. 2010) or time of foraging (Arcos et al. 2001, Spear et al. 2007). It is unclear, however, whether such segregation is due to competitive exclusion or simply reflects anatomical and behavioral adaptations to exploiting subtly different prey (e.g. Whittam \& Siegel-Causey 1981). When sympatric species are similar in size, dietary overlap can be high and environmental stochasticity seems to affect them similarly (Bryant \& Jones 1999). From a conservation perspective, overharvesting of marine organisms by fisheries can not only decrease prey availability for seabird communities, but also alter the ecological relationships among seabirds (Furness 2000, Montevecchi 2001, Votier et al. 2004). Generalist species, exploiting fishing discards or dumps, have steadily increased, in some cases, to the detriment of specialist seabirds because of interference competition at breeding sites or density-dependent competition for foraging resources. This is especially true when generalist species are large and aggressive, e.g. large gulls or skuas, and evidence suggests that human-induced changes have already altered the structure of seabird communities, although the broader ecological consequences of these shifts among conspecifics are unclear (Ainley \& Boekelheide 1990, Howes \& Montevecchi 1993, García Borboroglu \& Yorio 2007, Oro et al. 2009). Likewise, relatively little is known about the role of competitive exclusion in breeding habitat selection in seabird communities (Whittam \& Siegel-Causey 1981, Ainley \& Boekelheide 1990). Conservation actions can alter nesting environments, favoring certain species more than others within the community, and local extirpation of smaller seabirds by larger seabirds has been reported as a result of competitive exclusion in suitable nesting habitat (Oro et al. 2009).

Although predatory interactions among seabird species are less well studied than competitive interactions, they do occur (Gilchrist 1999, Votier et al. 
2004, Oro et al. 2006a, Oro \& Martínez-Abraín 2007). Large opportunistic species (e.g. gulls, giant petrels) can be facultative predators on smaller seabird species within the community, and population increases of the former following the appearance of large amounts of food from human activities may increase the predation rates on vulnerable species (Regehr \& Montevecchi 1997, Votier et al. 2004, Oro et al. 2006a). Seabirds may also more or less share parasites and pathogens that are prevalent in their breeding habitat, although the interactions involved are likely complex. Host specialization has notably been suggested for the common seabird tick Ixodes uriae (McCoy et al. 2005b), which can transmit several viruses and bacteria. Mutualism may also play an important role within some seabird communities, particularly in terms of prey detection (Jaquemet et al. 2005, Ainley et al. 2009). Some species are particularly good indicators of fish location for other seabird species, and changes in their numbers can have consequences for the whole community (Catry et al. 2009).

\section{At-sea spatial ecology}

Research on at-sea distributions of seabirds has served to clarify the role of seabirds in marine communities, identify important ecological areas and to predict avian responses to environmental changes in the marine environment. The central challenge is to understand how seabird spatial and temporal dynamics are linked to the spatial and temporal variability of prey and related oceanographic features. The 'classi$\mathrm{cal}^{\prime}$ age of at-sea investigation of seabirds occurred during the 1970-90s, when extensive data from shipping and other vessels were collected. During this period, there were major discoveries of the association of seabirds and seabird communities with specific oceanographic features (Brown et al. 1975, Pocklington 1979, Briggs et al. 1987, Wahl et al. 1989), and frontal zones at large spatial scales (Schneider et al. 1987), as well as more fine-scale features (e.g. Hunt \& Schneider 1987, Louzao et al. 2006) at smaller scales (Hunt \& Harrison1990, Hunt 1991). The advances in remote sensing, increased computation resources, and major developments in tracking technology have opened up even more opportunities to evaluate seabird associations with dynamic marine features, such that concurrent modeling of seabird and oceanographic data in a dynamic geospatial environment is possible (Tew Kai et al. 2009, Tremblay et al. 2009, Wakefield et al. 2009).

\subsection{How can we address knowledge gaps in at-sea distribution?}

A lack of detailed knowledge about at-sea distribution of individuals across species, sex and age classes has presented one of the most substantial challenges to seabird ecology. Satellite and global location sensor (GLS) devices deployed post-breeding have provided information on sex-related specific movements for adults (e.g. González-Solís et al. 2000). GLS logging uses the timings of sunrise, sunset and the resultant day length and timing of local noon to derive an estimation of global position. Subadults, unlike adults, spend years at sea, which precludes instrument retrieval, and as a result, little is known about their spatial distribution, except when plumage separation of age classes is possible (as for gulls, penguins, frigatebirds; Ainley et al. 1984, Diamond \& Schreiber 2002). Nevertheless, recent long-term deployment of GLS devices on juveniles may shed some light on this issue in the near future. Alternatively, the use of intrinsic markers, such as stable isotopes, genetics and trace elements, can provide valuable information on the broad-scale origin and movements of seabirds (Cherel \& Hobson 2007, Gómez-Díaz \& González-Solís 2007). Although data from intrinsic markers can provide only coarse-scale information, these methods represent a robust approach to mapping the spatial distribution of immatures, non-breeders or species too small for instrumentation. Information on at-sea distributions of seabirds has important applications. These data have been instrumental in defining Important Bird Areas (IBAs) and assessing potential interactions with anthropogenic factors such as some fisheries, shipping, oil spills or off-shore wind farms (Louzao et al. 2009). Aggregated, these data have been used to present the most comprehensive perspective on the global nature of seabird species (BirdLife International 2004, Halpin et al. 2009).

Remotely sensed oceanographic traits data and tracking technology also increase our understanding of seabird ecology and have shed new light on how seabirds associate with productivity gradients and biophysical discontinuities at several spatiotemporal scales (Ballance et al. 1997, Spear et al. 2001, Hyrenbach et al. 2006, Bost et al. 2009). In addition to distribution and movement, tracking devices can also be used to infer feeding activity of birds through the analysis of high resolution global positioning system (GPS) data, particularly when these data are combined with other devices, such as depth and activity recorders or stomach temperature loggers (Bost et al. 2008). Moreover, deployment of miniaturized sensors on diving seabirds 
can also provide data on hydrographic conditions, such as temperature and salinity, in foraging areas (Wilson et al 2002, Bost et al. 2008, Durant et al. 2009).

Further progress towards understanding seabird marine ecology will strongly depend on real-time investigations of ocean dynamics, both biological and physical. A sound theoretical framework considering a hierarchy of spatial scales has been developed to advance this research (Fauchald 2009). At-sea surveys combined with intensive synoptic multi-disciplinary investigations of ocean processes and food web dynamics, as well as tracking devices, can provide comprehensive information about at-sea behavior, and about what factors influence seabird distribution at the population and the individual level (Chapman et al. 2004, Ribic et al. 2008, Ainley et al. 2009). Projects such as GLOBEC exemplify this multi-disciplinary approach (www.globec.org).

\subsection{What habitat features delineate movement corridors or residency areas and how can researchers identify these corridors and quantify movement behavior?}

Seabird species vary in the extent and directionality of their movement patterns from within-region movement to long-distance migration. Networks of observers and radars have provided valuable multi-species information on seabird movements and timing of migration, although much of this information has been limited to coastal areas and specific vantage points (Mateos \& Arroyo 2010). At-sea investigations of seabird flight behavior can reveal movement patterns with sufficient environmental data (Spear \& Ainley 1999, Shaffer et al. 2006). Defining movement corridors between breeding colonies and foraging grounds or among breeding, staging and wintering areas depends on the combined use of several tracking systems. Integrating concurrent information from tracked individuals and remotely sensed ocean conditions can be used to identify broad-scale seabird movement (González-Solís \& Shaffer 2009, GonzálezSolís et al. 2009, Adams \& Flora 2010). The ongoing challenge to this research is the need to link high-resolution seabird location data with real-time data on physical and biological oceanographic conditions.

\section{Trophic dynamics and community roles of seabirds}

As top predators, marine birds are influenced by food web dynamics that can be changed and per- turbed by both top-down and bottom-up influences as well as by physical oceanographic shifts (e.g. Frederiksen et al. 2007). Anthropogenic influences associated with fisheries can induce pervasive top-down and indirect effects on food webs (e.g. Frank et al. 2005) and hence on apex avian predators. Seabird data are often used as a signal of shifts in marine food webs (Piatt et al. 2007). Synoptic vessel surveys, tracking studies and stable isotope sampling are providing comprehensive new information about the distributions, movements, activities, physical environmental measurements and foraging sites of seabirds throughout the year. Analytical methods for delineating core habitat areas are being integrated and refined. Risk analyses of anthropogenic factors associated with fishing, oil pollution, and shipping can be used to identify problem areas and to help resolve conflicts with adaptive management strategies.

\subsection{What are the roles of seabirds in communities} and food webs?

Understanding the role that seabirds play in communities and food webs is complicated by fluctuations in the ocean environment, the great distances covered by the seabirds and the associated difficulty of observing interactions of seabirds and their prey (Croxall et al. 1999). Consequently, the functional relationships between seabirds and their biotic and abiotic environments remain elusive (Grémillet et al. 2008). The technology to quantify habitat use by individual seabirds now exists, but quantitative analyses at appropriate scales are only just being used in hypothesis testing that could improve our understanding of the processes linking seabird distribution to their environment (Tew Kai et al 2009, Tremblay et al. 2009, Wakefield et al. 2009).

The marine environment is also subject to a variety of anthropogenic and natural stresses that affect marine productivity, stochasticity and cyclicity (Halpern et al. 2008, Grémillet \& Boulinier 2009). Consequently, marine food webs are often unstable and prone to regime shifts and numerous bottom-up and top-down controls so that any one event may have multiple causes and consequences. There is evidence of trophic cascades resulting from overfishing and the removal of large mammals and large predatory fishes in many open-ocean systems (Pauly et al. 1998, Frank et al. 2005, Baum \& Worm 2009). In the Ross Sea, where an immense upper trophic level community is built upon the high primary production of this region, Ainley et al. $(2004,2006,2007)$ showed that large 
numbers of competing top predators, including penguins, flighted birds, seals and whales, can decrease the available density of krill and fish prey species, thus reducing the grazing pressure on phytoplankton. As a result, a significant portion of phytoplankton remains ungrazed and sinks to the benthos, thus enriching that food web (Ainley et al. 2007).

The degree to which seabirds serve as indicators of trophic shifts within marine ecosystems varies with the species of seabird and their degree of prey specialization and the variability of their foraging behavior (e.g. Montevecchi \& Myers 1995, Croxall et al. 1999, Hamer et al. 2007). Seabird species that are dependent upon a limited array of prey species and may have less varied feeding methods are likely to exhibit more significant inter-annual variations in breeding frequency and success than those seabirds which feed on a wide variety of prey taken by a variety of feeding methods (Berrow \& Croxall 1999). However, trophic shifts triggered by intense largescale oceanic phenomena such as the ENSO and the NAO have been linked to severe negative impacts on both temperate and tropical seabird populations (Schreiber \& Schreiber 1984, Bertram et al. 2005; see Section 1.2). In general, these impacts are attributed to significant changes in productivity at lower trophic levels, (Devney et al. 2009) which result in reduced adult survival, a sudden drop in breeding frequency and/or complete breeding failure. The robustness of these studies indicates that, aside from catastrophic impacts of large-scale oceanic phenomena, studies of prey species composition, levels of prey harvest, and foraging duration of seabirds can provide reliable indices of prey abundance and thus serve as indicators of trophic shifts (Montevecchi \& Myers 1995, Croxall et al. 1999).

\subsection{How can we define, identify and map key foraging grounds?}

As discussed in Section 2.1, the earliest studies of at-sea distributions of seabirds were derived from ship-based surveys carried out opportunistically or on dedicated cruises (Harrison 1982, Haney 1985). Subsequent technological innovations have dramatically improved the capacity to track movements of individuals (Wilson et al. 2002, Phillips et al. 2007, Burger \& Shaffer 2008). Use of satellite-transmitters and, in recent years, GPS loggers have thus provided extensive, high-resolution distribution data from many medium to large seabirds during the breeding season. Increasing use of GLS technology has pro- vided low-resolution but, for some species, yearround data (Weimerskirch et al. 2002, Phillips et al. 2005, Rayner et al. 2008, Egevang et al 2010). Complementing the telemetry innovations, recent tracking data analyses have highlighted the importance of fronts, upwelling, eddies and other recurring ocean features that are indicators of high quality habitat with abundant sources of prey (Bost et al. 2009). With increasing awareness of natural and anthropogenic impacts on seabirds (e.g. the Convention on Biological Diversity [CBD] call to identify ecologically or biologically significant areas [EBSAs] in the high seas), more effort has been focused on mapping and characterizing key foraging grounds and resources.

A number of challenges have limited the ability to identify foraging areas. The first challenge is methodological: What analyses should be used to determine a foraging area? A suite of alternative approaches have been proposed that include kernel density estimates, track sinuosity, First Passage Time analysis and statespace models (Wakefield et al. 2009). As with other research questions, incorporating real-time remotely sensed environmental information (with appropriate measurement error) is an essential element to develop improved frameworks for integrating vessel-based and telemetric data, each of which suffers from known constraints (Louzao et al. 2009). To do this requires a range of device and data types, including immersion loggers, time-depth recorders, stomach temperature probes, accelerometers and multi-channel loggers (Weimerskirch \& Wilson 1992, Wilson et al. 2008), and experimental studies of the importance of olfaction (Nevitt \& Bonadonna 2005) in order to incorporate information on fine-scale behavior and sensory perception into feeding site identification. In addition, data on habitat accessibility and intra- and inter-specific competition (Grémillet et al. 2004) are needed to track habitat use as well as habitat preferences, and thus improve the capacity to predict spatial distribution of birds.

Identification of key prey resources is another component to understanding foraging requirements of seabirds (Pichegru et al. 2010). Conventional approaches to diet determination, which include visual observations of birds returning to colonies with prey in their bill, and sampling of stomach contents, pellets etc., are often effective during chickrearing, albeit with some inherent biases (Barrett et al. 2007). Understanding prey preferences outside of the breeding season is more challenging. With sufficient tissue samples, recent developments in the analyses of bulk and compound-specific stable isotopes, fatty acids, and other signature elements and 
compounds offer unprecedented opportunities to characterize diet in high taxonomic detail (Cherel et al. 2005, Connan et al. 2007, Käkelä et al. 2007, 2010). Seabirds offer high potential as indicators of broad-scale environmental change and of processes occurring at lower trophic levels, and therefore, by improving identification and characterization of their key areas, habitats and resources, seabird ecologists can make a vital contribution to current global initiatives to improve protection and sustainable management of the oceans.

\subsection{How do fisheries-mediated changes in trophic structure influence seabirds?}

Fisheries can change, and have clearly changed, and at times greatly perturbed marine food webs (Jackson et al. 2001, Hilborn et al. 2003, Estes et al. 2006). The effects of fisheries on marine birds are determined by the fisheries' target species, as well as the intensity, persistence and the spatial distribution of fishing effort. Human-induced changes in trophic structure can affect marine birds either negatively or positively (Montevecchi 2001). Fisheries (a top-down force) reduce the prey base and indirectly affect marine birds through prey depletion, a negative effect. However, fisheries may also reduce the number of competitors that rely on the same prey as seabirds, and this may yield a positive effect. These anthropogenic effects can interact with, and be amplified by, bottom-up ocean climate changes (Osterblom et al. 2007). Overfishing of large fishes can lead to increases in the abundances of smaller fishes. This is often evident when fisheries target large predators that can include pelagic species (Sherman et al. 1981), demersal species (Bundy 2005) or large marine mammals (Springer et al. 2003, Estes et al. 2006). Because it is the indirect relationships in food webs that are often pervasive, complexity often overrides straightforward rebounds of prey populations once predators are removed (Yodzis 2001). Fisheries can also have direct positive effects by providing food in the form of discards and offal that would otherwise be inaccessible to marine birds, yet the positive effects of discards vary across and within taxa (Garthe et al. 1996; see Section 4.4).

\section{Direct effects of fisheries}

As noted in Section 1, adult mortality has the most immediate effect on the population trends of seabirds. Incidental capture in fishing gear, called bycatch, is one factor that causes adult mortality and has been the focus of research and conservation concern since the late 1980s (e.g. Weimerskirch \& Jouventin 1987, Bartle 1991, Brothers 1991). Longline, trawl, and gillnet fishing gear can all lead to bird injury and mortality as birds forage for bait fish and discards. Different fishing gear types pose different threats to seabirds (Phillips et al. 2010). Birds scavenging or targeting baited longline hooks may get hooked and dragged under while the gear is at the surface. Trawl gear causes mortality primarily by birds striking cables. Diving birds may get entangled in gillnets while scavenging fish caught in the nets or pursuing forage fishes. Discarded fish parts, commonly called offal, may also provision some scavenging species, providing easily captured prey. Many researchers, agencies and governments have worked closely with industry to develop a wide range of seabird bycatch mitigation devices (Cherel et al 1996, Brothers et al. 1999, Melvin et al. 1999, 2001, 2004, O'Toole \& Molloy 2000, Boggs 2001, Robertson et al. 2003, Gilman et al. 2005). When used together, these devices have been shown to reduce seabird bycatch by more than $90 \%$ in some fisheries (Cox et al. 2007). Despite the increased awareness of the influence fisheries can have on seabird species and successful bycatch reduction by some fleets, basic questions remain on the extent of the negative and positive effects of fisheries on seabird populations.

\subsection{How can we obtain detailed, unbiased and accurate measures of bycatch rates?}

One of the central challenges to understanding the long-term effects of fisheries bycatch on seabird populations is the lack of detailed data on bycatch rates for individuals, species (versus taxa), colonies, as well as for age and sex classes within colonies (Gómez-Díaz \& González-Solís 2007). Given the importance of population sub-structure and movement for many seabird species (see Section1.4), understanding differential impact of fisheries bycatch among colonies is an essential component to understanding the magnitude and spatial extent of bycatch effects. Likewise, although bycatch leads to direct declines in survival rates, it may also have strong effects on subsequent fecundity and sex ratios (Mills and Ryan 2005).

Obtaining accurate estimates of bycatch rates per species, colony and age or sex class requires direct 
measurement from dead individuals, but also proper sampling design and statistical treatment (e.g. Laneri et al. 2010). Carcass collection, identification and analysis are instrumental in identifying species, sexing and aging the birds, to the highest resolution possible. With carcasses in hand, samples can also be collected for subsequent genetic analyses to further classify individuals to specific colonies, at least for species with clear population structure (Edwards et al. 2001, Gómez-Díaz \& González-Solís 2007). Existing carcass recovery programs point to sex-biased mortality in some regions. Bycatch research around the Prince Edward Islands found a strong adult male bias in bycatch mortality (Nel et al. 2002, Ryan \& Boix-Hinzen (1999) for 3 species (white-chinned petrel Procellaria aequinoctialis, grey-headed albatross Thalassarche chrysostoma and Indian yellownosed albatross T. carteri), whereas studies around New Zealand, South Georgia and the Crozet Islands have found adult female-biased bycatch mortality for grey petrels Procellaria cinerea and wandering albatrosses Diomedea exulans (Weimerskirch \& Jouventin 1987, Croxall \& Prince 1990, Murray et al. 1993). In some areas, the bias in capture is relative to age of the individual; juvenile seabirds may be disproportionately affected by gear interactions (Baker et al 2007). Genetic and post-mortem analyses of albatrosses carcasses from longline fishing gear in 2 New Zealand fishing areas illustrate the power of this approach to identify the age of individual, species caught, sex and colony of origin (Burg 2007).

The lack of widespread carcass-based work reflects, for the most part, the challenges involved in retaining large carcasses on space-limited fishing vessels. As with other analyses that consider the extent of mortality from a particular source, i.e. bycatch, oil contamination or storm events, there are also limitations from direct carcass measurements associated with factors that can lead to biases in carcass recovery, e.g. undetected carcasses that drop off or out of fishing gear (Ryan \& Watkins 2008), carcass degradation during gear deployments (Burg 2007), and changes in currents and ocean patterns in the case of beached carcasses (Lucas \& MacGregor 2006, Parrish et al. 2007). As with basic demographic parameter estimation, models provide one means of addressing these biases and improving estimates of total mortality (sensu Flint et al. 1999, Wiese \& Robertson 2004, Martínez-Abraín et al 2006, Veran et al. 2007). However, given the current data used, these models have limited ability to provide the high resolution estimates of mortality per colony, age or sex class.
4.2. How do we evaluate bycatch risk to different species or colonies in space and time?

A variety of methods have been used to evaluate the risk of fisheries bycatch to seabirds of different species, colonies, sexes and age classes (Piatt et al. 1984, Prince et al. 1992, Brothers et al. 1997, Weimerskirch et al. 2000). Traditionally, these approaches have included surveys of seabirds attending vessels by observers who record data on species and age classes, observations at colonies of information from banded and color-marked individuals, and wildlife telemetry which records individual-level data of tagged individuals. Increasingly, new approaches are being developed to search for evidence of fishery-related subsidies in seabird populations (e.g. stable isotopes; Votier et al. 2010) and to identify the provenance of bycaught individuals using genetics, morphometrics, or stable isotopes (Gómez-Díaz \& González-Solís 2007).

Following the fisheries management arena, the evaluation of bycatch risk can focus on the assessment of 'inputs' and 'outputs' into the system. Input variables quantify the risk to a given species or population component by quantifying its spatio-temporal overlap with fisheries effort. This approachhas 3 limitations: (1) it requires high-resolution concurrent data on seabird dispersion and fishing effort; (2) it relies on the underlying assumption that overlap is proportional to bycatch risk; and (3) it yields scaledependent risk metrics (for example, the degree of overlap and the statistical association between seabirds and fisheries' distributions vary with the temporal and spatial scales of analysis). Thus, empirical studies comparing these risk factors with actual bycatch rates would provide valuable insights into these underlying assumptions.

Output approaches quantify the effect of bycatch relative to population structure, e.g. age class, sex, and the geographic provenance (e.g. colony of origin) of bycaught individuals. While these data can, in theory, provide an absolute metric of bycatch risk of a single vessel, by comparing the contributions of different population segments to the observed bycatch, they cannot provide a comprehensive assessment of bycatch risk across all vessels within or among fleets. Unfortunately, the lack of fishery-independent data on seabird abundance and the differential reliance on fisheries among colonies and among age/sex classes limit the ability to scale the observed impacts across all vessels.

Integrated approaches capable of merging these input and output perspectives are critical to develop standardized bycatch risk assessments. To this end, studies should integrate input metrics (e.g. surveys of 
seabird distributions within fishing grounds, observations of vessel attendance) with output metrics (e.g. bycatch rates by sex- and age-class) from the same fisheries. In addition to determining the sex and age of bycaught specimens with necropsies, novel tracers are used to determine the provenance of bycaught individuals (Gómez-Díaz \& GonzálezSolís 2007). Efforts to develop an integrated picture of bycatch risk for specific seabird population components will benefit from the implementation of carcass retention and necropsy programs, and from the development of signature profiles for individual colonies. The final step of this integrated assessment entails ground-truthing population models with the bycatch composition data from the field (Moloney et al. 1994, Tuck et al. 2001).

New techniques and comprehensive applications are needed to effectively study the effects of fisheries on seabirds and other large marine predators. Integration of vessel surveys of birds at sea with mapping analyses derived from animal-borne tracking devices on free-ranging seabirds (Louzao et al. 2009) will provide the best means of understanding avian oceanic distributions and occupancy of sites. These space/time distributions have to be integrated with global databases and maps of fishing activities and catches to better identify ocean biological hotspots (Roberts et al. 2002) and to execute risk analyses involving areas of overlap, interaction and potential conflict (Karpouzi et al. 2007). These analyses need to be pursued on global, ocean-basin and regional scales (Bartumeus et al. 2010).

\subsection{What are the population-level effects of bycatch?}

As discussed in Section 1.1, the population-level impacts of incidental mortality are influenced by the species-specific life-history characteristics, including the sensitivity of population growth rate (lambda) to demographic parameters (adult survivorship vs. reproductive success), and by the differential susceptibility of different age classes and sexes to this mortality (Russell 1999, Weimerskirch 2002). Thus, population models consistently conclude that fisheries that preferentially kill breeding adults are expected to have a more drastic effect on lambda, since this age class has the highest survivorship rate and current reproductive value is the most influential on lambda (Piatt et al. 1984, Moloney et al. 1994, Cousins 2001).

In turn, the susceptibility of different sexes and age classes to bycatch is expected to be influenced by dif- ferential rates of interaction with fisheries. There is mounting evidence that different age classes (e.g. Suryan et al. 2007) and sexes (e.g. Nel et al. 2002) within a species differ in their overlap with fisheries, due to the segregation of at-sea distributions and differences in foraging ecology. While the influence of this ecological segregation on bycatch risks has been documented, especially for sexually dimorphic species, (e.g. Prince et al. 1992, González-Solís et al. 2007), the degree to which different age classes rely on fisheries is not well understood (but see Bartumeus et al. 2010, Votier et al. 2010). In particular, it is essential to know whether young birds are more susceptible to fishing gear, and whether this higher susceptibility is caused by their lack of experience or by a higher likelihood for younger birds to forage at fishing vessels.

An improved assessment of population-level effects of bycatch requires 3 ingredients. First, these impacts need to be evaluated in a population-level context. This requires an understanding of the magnitude (number of individuals as a proportion of the total population) and data on the differential risk to certain individuals (i.e. birds that specialize on fisheries) or age classes (i.e. young of year). This information is critical for developing population metrics of bycatch risk using data on spatial overlap (Prince et al. 1992) or vessel attendance (Weimerskirch et al. 2000). Second, it is imperative to place these species-specific bycatch risks in a broader demographic context by balancing the resulting bycatch mortality against the benefits of food subsidies, which may be critical food resources for inexperienced birds during their first years at sea or during periods of low prey productivity. Third, because the degree of vessel attendance and the benefits versus costs associated with this behavior are likely influenced by the presence of competitors, it is critical to investigate how seabird-fishery interactions, such as access to baited hooks and foraging success, are influenced by the presence and density of other species. Without this community-level understanding, bycatch mitigation measures attempting to minimize the take of one protected species may cause unintended impacts on other species. For instance, night-time sets designed to avoid the competitively dominant largebodied albatrosses, appear to increase the bycatch of petrels and shearwaters (Cherel et al. 1996).

\subsection{What are the positive and negative effects of discards in provisioning seabirds?}

It is estimated that 7.3 million $t$ of fish are discarded annually by marine fisheries throughout the world 
(Kelleher 2004). Although this estimate is lower than in previous decades (Alverson et al. 1994), when considered in conjunction with associated overfishing, discards are likely to exert significant impacts on seabirds (Furness 2003). A common and overabundant food source, discards have artificially inflated scavenging seabird populations (Furness et al 1992, Garthe et al 1996), probably due to improved body condition and breeding performance (Bunce et al. 2002, Oro et al. 2004, Votier et al. 2008a). Documented increases in northern fulmars in the North Sea have been ascribed, in part, to food subsidies from fisheries discards (Camphuysen \& Garthe 1997, Thompson 2006).

Although discards may serve as an important resource for some seabird populations, they have also been documented to have a negative influence on other seabird populations (Kitaysky et al. 2006, Pichegru et al. 2007, Österblom et al 2008, Grémillet et al. 2008, Navarro et al. 2009). The long-term impacts of discards on seabirds, both positive and negative are still emerging (Arcos et al. 2008, Bartumeus et al. 2010). The proportion of foraging individuals or age classes relying on discards is unclear (but see Navarro et al. 2010), as is whether species are developing discard specialization. As discussed in Section 1.2, generalist species that exploit fishing discards have steadily increased, in some cases, to the detriment of specialist seabirds. A combination of diet studies, biomarkers (e.g. fatty acids, stable isotopes) and field studies is needed to effectively study how discards are influencing demographic parameters and population dynamics.

\section{Global change and population response to environmental variability}

Human-induced disruption of ocean resources has had a profound effect on ocean food webs and communities, although the magnitude of these effects is not easily detected (Pauly 1995, Pitcher 2001, Pauly \& Maclean 2003). Even the carrying capacity of once rich areas has been severely reduced (Christensen \& Richardson 2008, Watermeyer et al. 2008a,b). In this context, global-scale environmental changes, particularly rising temperatures, retreating sea ice and ocean acidification, are expected to be the dominant anthropogenic pressures on marine ecosystems in the next decades (Harley et al. 2006). These effects are exacerbated by the simplification of food webs owing to fish depletion (Cury et al. 2000, Osterblom et al. 2007, Watermeyer et al. 2008a,b). Current and projected changes are rapid and large, and conditions are likely to shift to entirely novel states (Solomon et al. 2007). Understanding how seabird populations are affected by changing conditions is therefore critical to support the development of efficient conservation efforts. Research needed to advance understanding of these issues includes integrated comparisons across study sites, eco-physiological studies, and collaborations with researchers working on other trophic levels and on physical variables (e.g. physical oceanographers, climatologists).

\subsection{How resilient are seabirds to climate and related environmental change?}

Meaningful conservation efforts for seabirds in the 21st century need to take into account how resilient populations and species are to climatic and other oceanographic changes. Will seabirds be able to change their breeding and non-breeding ranges, foraging habitats, diets etc. sufficiently quickly to keep up with the increasing pace of change (Grémillet \& Boulinier 2009)? Can change through phenotypic plasticity facilitate adapation, or will evolutionary processes make seabird survival possible? These questions cannot profitably be addressed for all seabirds, because species differ widely in life history characteristics, exposure to other stressors and, thus, in resilience. A wide variety of research tools, applied at different organizational levels, will be necessary to provide answers for seabird species, communities and ecosystems.

At the individual level, we need to understand to what extent seabirds can adapt to the direct, e.g. increasing temperatures, and indirect effects of environmental change from changes in prey availability. Ecophysiological studies play an important role, both in an experimental, captive setting and for free-ranging birds in their natural environment (Gaston et al. 2009). Empirical studies of energy balance, e.g. including experimental manipulation of food supply, can provide information on the limits of phenotypic plasticity in terms of adapting to changing food availability and quality (Enstipp et al. 2007). Energetics modeling has also been demonstrated as a viable means of assessing the impact of environmental change on seabird energy balance (Fort et al. 2009). Likewise, studies of thermal tolerance will allow the construction of species-specific Scholander curves, characterising the lower and upper critical temperature thresholds as well as the temperature comfort zone (Scholander et al. 1950). 
In order to affect populations, impacts of environmental change on seabirds must manifest themselves as changes in demographic parameters (reproduction, survival and dispersal). Estimating realized changes in these parameters requires data from long-term studies, preferably of marked individuals (Barbraud \& Weimerskirch 2003, Frederiksen et al. 2004). Although such studies are by their nature correlational and cannot be used to draw strong conclusions about causal relationships, they allow inference about processes on a temporal and spatial scale that is unattainable for experimental studies. In particular, combining data from several geographically separated populations allows a degree of replication and has the potential to provide information on a rangewide scale (Grosbois et al. 2009). Data on at-sea distributions can be treated in a similar way, although the specific statistical methods differ.

There is an increasing realization that evolutionary processes commonly occur on an ecologically relevant time scale, and in order to assess how organisms adapt to directional environmental change, an understanding of selection pressures and associated responses is necessary. However, estimating heritability and separating phenotypic plasticity from microevolution in wild animals is challenging, particularly because detectability (e.g. recapture or resighting probability) is generally less than one (Gimenez et al. 2008). The most promising approach is based on long-term studies with extensive pedigree information, but such studies are rare (Doligez et al. 2009, Ozgul et al. 2009).

To predict the consequences of environmental change on distribution, abundance or viability of whole species or communities, modeling tools are needed (Watermeyer et al. 2008a,b). At the simplest and most phenomenological level, climate envelope and similar models predict future breeding or nonbreeding distributions based on current empirical associations between the presence of a particular species and various aspects of climate (Guisan \& Thuiller 2005). Such models may be more suitable for non-breeding distributions where detailed information about individuals is limited, particularly if they can be linked to models of the future distribution of important prey organisms (see Section 5.2), or for species breeding on low-lying islands threatened by sea level rise. A more mechanistic approach uses matrix-based population models, which are parameterized with the results of demographic studies, including any observed relationships between demographic performance and climate (Caswell 2001). Finally, the most complex approach uses the results of studies of individual behavior, diet, and energetics directly to predict the fate of individuals constituting virtual populations (Sutherland \& Norris 2002, Fort et al. 2009). Such behavior-based (or agent-based) models are potentially highly realistic, but also very difficult and resource-demanding to parameterise. The choice of modeling approach should depend on the specific questions and the data at hand.

5.2. What are the likely cascading trophic effects on seabird population from environmental change?

Marine ecosystems are and will be strongly affected by increasing temperatures and acidification due to increasing atmospheric $\mathrm{CO}_{2}$ concentrations. Increasing temperatures lead to changes in ocean currents, primary productivity (Behrenfeld et al. 2006), decreasing ice coverage in polar regions and distribution of key species at lower trophic levels (Richardson \& Schoeman 2004, Perry et al. 2005). The long-term biological consequences of acidification are still poorly understood, but organisms reliant on calcium carbonate exoskeletons are likely to be severely impacted as pH decreases (Orr et al. 2005). In polar regions, the physical changes related to the gradual disappearance of sea ice are also likely to have far-reaching ecological implications (Hunt et al. 2002, Stempniewicz et al. 2007, Gaston et al. 2009). All these expected changes will mean that the favoured prey organisms of many seabirds will change in abundance or shift their distributions, and this will inevitably affect seabird energy balance, demography and ultimately abundance and distribution. In temperate and polar regions, such indirect effects are likely to be more important than direct physiological effects for most species, and seabird responses to climate change may vary according to diet (Kitaysky \& Golubova 2000).

It is often assumed, in the present state of the world ocean, that bottom-up control is the most important mechanism structuring marine ecosystems (but see Pauly \& Maclean 2003). However, top-down control is likely to also be important under certain conditions, and indeed it is possible that climatic changes may affect the balance between these 2 mechanisms (Hunt et al. 2002). This implies that changing seabird and other upper predator populations under some circumstances can affect the abundance and/or distribution of their prey, and that this can have farreaching ecological implications, even those that deviate from traditional trophic cascade patterns 
(Cury et al 2000, Nicol et al. 2010). It is therefore important that model representations of trophic effects rely on empirical information on the relative importance of bottom-up and top-down control, rather than on standard assumptions.

Understanding these trophically mediated effects and predicting their consequences requires collaboration with researchers working in physical and biological oceanography, marine ecology and fisheries science. Unfortunately, in many parts of the world there is a lack of relevant long-term, large-scale in situ data sets, although there are notable exceptions (e.g. the Continuous Plankton Recorder survey, Reid et al. 2003). Satellite telemetry data can partly fill this gap, as they allow estimation of, for example, primary productivity with a high spatial resolution and coverage (Behrenfeld \& Falkowski 1997). Appropriate statistical modeling tools such as Bayesian approaches are needed to establish the strength of trophic links and predict consequences for seabirds (Clark 2005).

5.3. How do interactions at different hierarchical scales affect seabirds' responses to environmental change?

Interactions with conspecifics in seabird colonies are widely viewed as accruing net fitness benefits, for example through enhanced protection from predators (Birkhead 1977). Under conditions of low prey availability, parents may need to forage simultaneously, leaving their offspring temporarily unattended (Regehr \& Montevecchi 1997). Except in cannibalistic species (Hamer et al. 1991), such unattended chicks may be expected to gain protection within colonies from the proximity of neighbouring birds, providing parents with a buffer against adverse foraging conditions. However, recent evidence has indicated that in the absence of cannibalism, chicks left unattended by their parents may nonetheless be attacked and killed by adults from neighbouring sites (Ashbrook et al. 2008) in addition to being attacked by non-breeders attempting to usurp sites (Anderson et al. 2004, Hamer et al. 2007). These data indicate potential shifts in the cost-benefit of breeding at high density (Danchin \& Wagner 1997), especially when food conditions are poor and suggest a growing need to understand how environmental changes affect behavioral and social interactions within colonies.

Some of the most powerful data concerning responses of seabirds to different environmental pressures have derived from long-term studies of focal populations (e.g. Frederiksen et al. 2004, Grosbois \& Thompson 2005, Österblom et al 2007, Montevecchi 2009). Few studies, however, have considered responses to environmental forcing in the context of interactions within population networks, which may have important population dynamic consequences (see Coulson 1991 for an exception). For instance, Sandvik et al. (2008) reported a positive relationship between sea surface temperature (SST) and the breeding success of a wide range of North Atlantic seabirds. For several of the species included in this analysis, however, warming also had a negative effect on annual adult survival (Grosbois \& Thompson 2005, Sandvik et al. 2005, Votier et al. 2005). In a circumpolar analysis of breeding murre populations, Irons et al. (2008) demonstrated that the Arctic species, thick-billed murre Uria lomvia, responded most positively when SST warmed slightly and that the temperate species, common murre U. aalge, exhibited rapid increases when SST cooled moderately. Most interestingly, both species responded negatively to large shifts in SST regardless of whether the change was in the positive or negative direction.

Sites with high breeding success are likely to be attractive to prospecting non-breeders (Danchin et al. 1998), although this may not lead to reproductive success after recruitment if these birds experience relatively low survivorship post-recruitment. For seabirds, adult survival has much greater elasticity than annual breeding success, which suggests that some breeding sites may act to some extent as population sinks (Hamer 2010), notably if predators affect the survival of individuals at some locations. For instance, a recent study in Alaska, USA, found a positive relationship between SST and the breeding success of piscivorous auks (Alcidae) but a simultaneous decline in breeding population sizes (Slater \& Byrd 2009). It is not clear whether these declines occurred despite increased recruitment from other colonies. This suggests that meta-population and source-sink dynamics will become increasingly important features of seabird conservation efforts in the future (Lebreton et al. 2003, Cam et al. 2004, Zador et al. 2009).

An additional challenge to understanding the effect of climate change on seabirds is the differential rates of environmental change in marine and terrestrial environments. For instance, impacts of climate change on prey availability at sea and direct physiological impacts on birds at the nest may show different patterns of temporal and spatial variation, 
leading to an increasing disparity between where and when birds can nest and where and when they can locate sufficient prey to feed themselves and their offspring (Grémillet \& Charmantier 2010). Direct physiological effects have typically been viewed as relatively unimportant (Durant et al. 2004) but are likely to increase in prominence with continuing climatic warming in most regions, leading to a growing need for combined studies of both types of effect and their synergistic interactions to predict how the geographical distributions of different species are likely to alter in response to continuing climate change (Oswald et al. 2008). For instance, several statistical approaches are available to describe the climate envelopes of different species and predict how these envelopes will shift under different climate change scenarios (Huntley et al. 2007). Further work is required, however, both to refine the models themselves, i.e. to include both direct and indirect effects, and to refine their predictions by incorporating information on dispersal, recruitment and colony formation processes in addition to other factors likely to impede or facilitate geographical range shifts (Mustin et al. 2007, Grémillet \& Boulinier 2009). In marine systems with relatively low productivity, annual stochasticity in river flows is known to influence the population dynamics of small pelagic fish, which are the main prey for many seabird species (Lloret et al. 2004). Hence, in such systems the interactions between climate change, human perturbations in terrestrial ecosystems (e.g. presence of dams and pollutants in major rivers) and seabirds may be particularly strong. Integrated research which takes into consideration the natural and altered patterns of spatiotemporal variability of the environment as well as the mechanistic processes of population responses (including ecophysiology, demography, and behavior) is required.

\section{Managing anthropogenic impacts (invasive species, contaminants and protected areas}

As a consequence of the increasing intensity and diversity of threats that they face both on land and at sea, seabirds have become increasingly threatened at a faster rate than any other bird group in recent decades (Boersma et al. 2002, Butchart et al. 2004). One of the most relevant direct threats at sea, fisheries, was covered in Section 4. However, there are other anthropogenic impacts that also have a substantial effect on seabird populations, namely inva- sive species and pollution. Here, we also focus particular attention on one important conservation tool used to address many of these threats, the implementation of protected areas.

\subsection{What are the population-level impacts of invasive species?}

That seabirds have not evolved to respond to terrestrial predation by vertebrate predators is a well-known phenomenon. Most seabirds breed on islands or isolated patches to avoid terrestrial predators. Unfortunately, alien fauna associated with humans and marine traffic trade has accessed isolated breeding areas; this has led to drastic reductions, and extinctions, in some seabird populations. Direct predation by non-native animals (mainly rats, feral cats and other carnivores) is the most studied type of invasive species; however, there are others less known but equally deleterious, such as invasive grazers or plants, which can also have negative impacts on breeding habitat suitability by causing changes in vegetation structure, trampling of nests or erosion (see review in Boersma et al. 2002).

Several factors influence the level of impact of nonnative species on seabirds: first, the body size of both the predators and the seabirds. Feral cats or other medium-sized carnivores (such as Mustelidae) can prey on a large range of seabird species (including adults) from storm petrels to albatrosses, and thus can have a drastic effect on their populations (Courchamp et al. 2003). Because they are able to gain access to small burrows, rats and mice can have a greater impact on smaller species, e.g. terns and smaller petrels, by preying on nests and adults, and the presence of non-native carnivores is incompatible with viable populations of these seabirds (Martin et al. 2000, Angel et al. 2009). Rats and mice (Cuthbert \& Hilton 2004, Wanless et al. 2009) can also prey on eggs and small chicks of larger seabirds - even albatrosses - although many of these populations are able to buffer this impact. The best example of seabird resilience to an invasive predator is the cohabitation of shearwaters and rats on Mediterranean islands (Ruffino et al. 2009). The world's largest colony of Leach's storm petrel Oceanodroma leucorhoa on Baccalieu Island in the northwest Atlantic has been co-inhabited by red foxes Vulpes vulpes for about a century (Montevecchi \& Tuck 1987). The foxes prevent large ground-nesting gulls, which also take a large toll of storm petrels (Stenhouse et al. 2000), from nesting on the island. 
Knowing which life-history stage is most affected by the presence of an invasive species is also crucial to determining the rate and severity of the impact on seabird population dynamics: invasive plants, grazers (such as rabbits, or cattle) or rodents mainly affect reproduction (through reduced nest site availability and/or quality or decreased breeding success), and their impact tends to be relatively low compared to that of alien species which reduce adult survival (see Section 1.1). Some species can buffer such disturbances by dispersing to safer sites, particularly those species with nomadic strategies, such as some gulls and terns (Oro et al. 1999), whereas less plastic species may be less able to react to predators (Igual et al. 2007, but see Bonnaud et al. 2009). Finally, the breeding habitats of seabirds can also influence the impact of non-native species: burrowing species, compared to open-habitat species, are better protected against mice, rats and relatively large carnivores (Igual et al. 2006, Bourgeois \& Vidal 2007). Cliff-nesting species are the best protected against all types of invasive species owing to their relative large and inaccessible nests.

Seabirds are similarly threatened by invasive plant species, which have been documented to negatively impact breeding activity (Van der Wal et al. 2008). Invasive plants reduce nesting success by decreasing available nesting habitat, entrapping or obscuring chicks, and by increasing the abundance of insects that may threaten eggs or chicks. In addition to preventing breeding or curtailing the success of breeding birds, by reducing seabird abundance in general both plant and mammal invasive species can alter nutrient content and soil composition, causing widespread effects across an entire area (Hawke \& Clark 2010).

The best means of controlling alien species is to reduce their numbers, or when possible, to eradicate them (Courchamp et al. 2003). To assess the success of these programs, studies evaluate correlated changes in seabird parameters such as breeding output and adult survival, with different densities of alien species. This can be based on direct observation (Nogales et al. 2004, Igual et al. 2006) or can use non-invaded sites as controls (Ratcliffe et al. 2010). Because of the complex community interactions involved, eradications of invasive species may have unexpected results, e.g. the substitution of an eradicated predator by an ecological competitor occupying the same niche (Courchamp et al. 2003, Martínez-Abraín et al. 2004, Rayner et al. 2007). Nonetheless, eradication and invasive species control remains an important conservation issue for seabird colonies worldwide.
6.2. What is the population-level influence of contaminants and other pollutants?

Human activities generate a range of pollutants that are widely distributed across the seas, because of the unfettered nature of transport in aquatic environments (see Halpern et al. 2008). Pollutants include hydrocarbons, heavy metals, hydrophobic persistent organic pollutants (POPs), and small plastic debris. Since seabirds are at or near the top of marine food webs, they are particularly sensitive to these pollutants (see review in Burger \& Gochfeld 2002). For the same reason, seabirds are excellent tools to monitor temporal and spatial trends of pollutants in the marine environment (Furness 1993).

Oil spills are a prevalent common cause of anthropogenically caused mass mortality in seabirds. Munilla et al. (2007) reported as many as 20 shipwrecks involving the release of oil or other hazardous products into the Atlantic waters of the Iberian Peninsula from 1957 to 2002. Since 1948, at least 13 major petroleum spills have caused direct mortality in at least 500 African penguins (Underhill 2007). Some of these catastrophes have had dramatic effects on breeding seabird populations due to direct mortality and depletion of food sources (Velando et al. 2005a,b, Votier et al. 2005, 2008b, MartínezAbraín et al. 2006).

Pollutants affect seabirds in many different ways, at both individual and population levels (Burger \& Gochfeld 2002). Direct mortality is the most obvious effect, particularly when it is related to point-source pollution such as oil spills and illegal discharges of oily bilge water and tank flushings, which can kill large numbers of birds in a short time period (Piatt et al. 1990). However, sub-lethal effects can also be very important, affecting development, physiology and behavior, and ultimately reproductive performance and survival rates (Finkelstein et al. 2006). Pollutants can also affect seabirds indirectly by altering their habitat structure and prey availability. Assessing sub-lethal effects on an individual requires a combination of laboratory and field studies. Examining the toxic residues, their metabolites and biochemical markers indicating the stress and tissue damage is a useful tool (Burger \& Gochfeld 2002).

Assessing the impact of pollutants on seabirds at the population level is also extremely challenging. The population decreases seen in some seabird species are believed to be associated with exposure to high levels of dichlorodiphenyldichloroethylene (DDEs) and polychlorinated biphenyls (PCBs) in North America during 1950s and 1960s (Hatch \& 
Kubiak et al 1989, Weseloh 1999, Nisbet 2002), although direct tests are lacking. Even in the case of acute pollution events causing large numbers of casualties it is difficult to directly link a pollutant to mortality because of compensatory changes in recruitment, reproductive and survival rates (Wiens 1996) and changes in prey availability caused by such acute events (Peterson et al. 2003, Velando et al. 2005a). The analysis of long-term population data sets can shed some light on this topic (Votier et al. 2005, 2008b, Martínez-Abraín et al. 2006), especially those studies that have focused on vulnerability to different levels of pollution of POPs and plastics (Finkelstein et al. 2006, Young et al. 2010).

\subsection{How effective are protected areas in protecting seabirds?}

Historically, seabirds have received protection in many of their breeding colonies across the world, and have benefited greatly from it (Grémillet \& Boulinier 2009). Indeed, the designation of seabird nesting sites as protected areas has prevented direct human impacts such as harvest and habitat destruction. Moreover, active management focused on some of these places has also helped to reduce threats posed by non-native and invasive species, human visitation, and disease introduction (Weimerskirch 2004, Rauzon 2007). This has resulted in positive effects at the population level (Furness \& Monaghan 1987, Grandgeorge et al. 2008), although current seabird declines worldwide related to threats at sea demonstrate that complementary conservation strategies, including the implementation of Marine Protected Areas (MPAs), are necessary (Hyrenbach et al. 2000, Grémillet \& Boulinier 2009).

The protection of marine areas for seabirds has lagged behind terrestrial sites, with efforts so far concentrated in the areas adjacent to seabird colonies (Airamé et al. 2003, Wilson et al. 2008, Yorio 2009, Pichegru et al. 2010) and, to a lesser extent, in coastal and/or shallow areas for highly aggregated wintering species (Skov et al. 2007). However, the rapid development of tracking technologies, along with the proliferation of boat-based seabird surveys and the development of analytical tools to assess distribution patterns and habitat preferences, has recently attracted attention to MPA design for seabirds and other marine megafauna, particularly in pelagic water (see Section 2, Hooker \& Gerber 2004, Hyrenbach et al. 2006, Louzao et al. 2006, 2009, Skov et al. 2008, Game et al. 2009). Ongoing research has been aided by the international commitment to protect at least $10 \%$ of each representative habitat of the globe by $2010 / 2012$, including the high seas, under the CBD (Coad et al. 2009). Within this framework, BirdLife International has chosen as a priority the extension of its IBA Programme to the marine environment (BirdLife International 2004), providing an excellent opportunity for the inventory of seabird hotspots at a global scale. Pioneering examples are the recently completed inventories of marine IBAs in Portugal and Spain (Ramírez et al. 2008, Arcos et al. 2008). Protecting marine areas outside of national jurisdictions, i.e. 'high seas areas', however, remains a huge problem.

Given the high mobility of seabirds, MPAs cannot guarantee their complete protection at sea (Boersma \& Parrish 1999). However, seabirds often show high predictability, foraging recurrently in the same areas at mid-scale (Davoren et al. 2003, Weimerskirch 2007); hence protecting their most relevant foraging areas by restricting or mitigating fishing activities is expected to benefit seabird populations. To date, the limited number of MPAs in high-seas areas utilized by seabirds has hampered the ability to evaluate their efficacy for seabird conservation (but see Pichegru et al. 2010)

The high mobility of seabirds makes it necessary to work on a large-scale, network perspective, combining the efforts from different national and international jurisdictions (Boersma \& Parrish 1999, Lewison et al. 2005, Lipcius et al. 2005, Croxall 2008, Yorio 2009). It is also crucial to integrate MPAs into a wider view of marine ecosystem management and conservation (Boersma \& Parrish 1999, Hyrenbach et al. 2000). In this context, Marine Spatial Planning allows a more integrated approach, as it includes an interlinked system of plans, policies and regulations of resources and spaces with strategies that apply beyond the traditional MPA boundaries (Gubbay 2004, Ehler \& Douvere 2009). Likewise, it is important to consider how the protection of land and at-sea areas can be designed to directly support seabird conservation in the context of annual and long-term changes in habitat suitability and potential range shifts (Grémillet \& Boulinier 2009).

\section{DISCUSSION}

Seabirds are often referred to as biological indicators or sentinel species because they exhibit clear and relatively rapid responses to large-scale environmental variability and human disturbances of marine 
ecosystems (Piatt et al. 2007). Decades of seabird research have strengthened our ecological understanding of the role of seabirds in marine ecosystems, through the development of long time series of productivity, population abundance, and demography (e.g. Thompson et al. 1995, Frederiksen et al. 2004, Sydeman et al. 2009). Additionally, novel conceptual and technological advances have revolutionized our ability to monitor these animals both over fine-scales using GPS technology and over large scales using GLS loggers (see review by Burger \& Shaffer 2008).

Despite a rich history of seabird research and increasingly more sophisticated research tools, protecting and conserving seabird populations is limited by a lack of fundamental ecological knowledge across a range of research questions. Using a geographically and epistemologically diverse group of seabird experts, the present exercise was designed to identify the most important information gaps as a way of prioritizing future research for seabird populations and to increase the applicability of seabirds to the management of marine systems. Recent articles by Sutherland et al. $(2006,2009)$ highlight the value of expert opinion for identifying pertinent research questions that may facilitate and guide wildlife conservation, and similar efforts with other species groups have been fruitful (Hamann et al. 2010). This exercise confirms the notion that our ability to respond to seabird declines is hampered by data gaps, but also by a limited understanding of the interplay between spatio-temporal variability of the environment, notably at large spatial scales, and the demographic, behavioral and ecophysiological responses of populations.

As indicated by the list of the topics identified, seabird research priorities span several disciplines: population ecology, geospatial mapping and analysis, resource management, and biological and physical oceanography. The breadth of knowledge and expertise required to tackle these questions highlights the need for collaboration across disciplines. Furthermore, many of these questions and subquestions are fundamentally linked conceptually or logistically. The connections and overlap among the research priorities underscores the breadth of knowledge and expertise required to tackle these questions and highlights the need for integrated research approaches and synthesis. By engaging in multi-disciplinary research projects, seabird ecologists can integrate the diverse range of datasets required to tackle these complex questions. Integrative research efforts contextualize research questions by bringing together disparate datasets to assess large-scale pat- terns or trends (e.g. OBIS-SEAMAP) and facilitate the development of novel conceptual and quantitative approaches. Integrative research can also facilitate the implementation of specific experimental approaches and the design of large-scale replicated studies to allow stronger inference about the causal links between variables of interest (Yoccoz et al. 2001). There is evidence of a similar trend towards interdisciplinary research in related fields (Hart \& Hyrenbach 2009).

Rather than provide a comprehensive evaluation of the long-term research priorities for seabird conservation, the list generated here is a 'snapshot' of the research needs of today's seabird populations. Given the dynamic nature of seabird populations and their environment, our expectation is that the priorities themselves will also change. There is also likely to be regional variability in the relative importance among the priorities. So rather than provide a fixed 'recipe', this exercise serves as a starting point for more focused analyses to rank the priorities across regions and habitats. It is our assumption that the relative importance and current understanding of each priority will vary among regions (e.g. polar, sub-polar, temperate, tropical), and ocean domains (e.g. coastal waters, continental shelves, oceanic waters).

While natural and social science plays an important role in addressing fundamental knowledge gaps, it does not replace the need for directed management and policy to protect seabird populations. The synergy of applied research and conservation management is an essential ingredient to help ensure the viability of seabird populations and global ocean ecosystems around the world. It is our hope that any future research which tackles the priorities identified here will serve as an important complement to management plans, policy and legislation.

Acknowledgements. Our thanks to the dedicated and patient ESR reviewers and editors who helped improve and strengthen this work.

\section{LITERATURE CITED}

Abbott CL, Double MC (2003) Genetic structure, conservation genetics and evidence of speciation by range expansion in shy and white-capped albatrosses. Mol Ecol 12: 2953-2962

Adams J, Flora S (2009) Correlating seabird movements with ocean winds: linking satellite telemetry with ocean scatterometry. Mar Biol 157:915-929

- Aebischer NJ, Coulson JC, Colebrookl JM (1990) Parallel long-term trends across four marine trophic levels and weather. Nature 347:753-755 
Ainley DG, Boekelheide RJ (1990) Seabirds of the Farallon Islands: ecology, dynamics, and structure of an upwelling-system community. Stanford University Press, Stanford, CA

Ainley DG, O'Connor EF, Boekelheide RJ (1984) The marine ecology of seabirds in the Ross Sea, Antarctica. Ornithol Monogr No. 32. Am. Ornithological Union, Washington, $\mathrm{DC}$

Ainley DG, Ribic CA, Wood RC (1990) A demographic study of the South Polar skua Catharacta maccormicki at Cape Crozier. J Anim Ecol 59:1-20

Ainley DG, Ribic CA, Ballard G, Heath S and others (2004) Geographic structure of Adelie penguin populations: size, overlap and use of adjacent colony-specific foraging areas. Ecol Monogr 74:159-178

Ainley DG, Ballard G, Dugger KM (2006) Competition among penguins and cetaceans reveals trophic cascades in the western Ross Sea, Antarctica. Ecology 87: 2080-2093

Ainley DG, Ballard G, Ackley S, Blight LK and others (2007) Paradigm lost, or is top-down forcing no longer significant in the Antarctic marine ecosystem? Antarct Sci 19: 283-290

Ainley DG, Dugger KD, Ford RG, Pierce SD and others (2009) Association of predators and prey at frontal features in the California Current: competition, facilitation, and co-occurrence. Mar Ecol Prog Ser 389:271-294

> Airamé S, Dugan JE, Lafferty KD, Leslie H, McArdle DA, Warner RR (2003) Applying ecological criteria to marine reserve design: a case study from the California Channel Islands. Ecol Appl 13(Suppl 1):170-184

Alverson DL, Freeberg MH, Pope JG, Murawski SA (1994) A global assessment of fisheries bycatch and discards. FAO Fish Tech Pap 339

Anderson DJ, Porter ET, Ferree ED (2004) Non-breeding Nazca boobies (Sula granti) show social and sexual interest in chicks: behavioral and ecological aspects. Behavior 141:959-977

Angel A, Wanless R, Cooper J (2009) Review of impacts of the introduced house mouse on islands in the Southern Ocean: Are mice equivalent to rats? Biol Invasions 11: 1743-1754

> Arcos J, Oro D, Sol D (2001) Competition between yellowlegged Larus cachinnans and Audouin's gulls Larus audouinii associated with commercial fishing vessels: the influence of the season and the fishing fleet. Mar Biol 139:807-816

Arcos JM, Louzao M, Oro D (2008) Fishery ecosystem impacts and management in the Mediterranean: seabirds point of view. In: Nielsen JL, Dodson JJ, Friedland K, Hamon TR, Musick J, Verspoor E (eds) Reconciling fisheries with conservation. Proc Fourth World Fisheries Congress, American Fisheries Society, Symposium 49, Bethesda, MD, p 1471-1479

Ashbrook K, Wanless S, Harris MP, Hamer KC (2008) Hitting the buffers: conspecific aggression undermines benefits of colonial breeding under adverse conditions. Biol Lett 4:630-633

Ashmole NP (1968) Body size, prey size, and ecological segregation in five sympatric tropical terns (Aves: Laridae). Syst Zool 17:292-304

Avise JC, Nelson WS, Bowen BW, Walker D (2000) Phylogeography of colonially nesting seabirds, with special reference to global matrilineal patterns in the sooty tern (Sterna fuscata). Mol Ecol 9:1783-1792
Baker GB, Double MC, Gales R, Tuck GN and others (2007) A global assessment of the impact of fisheries-related mortality on shy and white-capped albatrosses: conservation implications. Biol Conserv 137:319-333

Ballance LT, Pitman RL, Reilly SB (1997) Seabird community structure along a productivity gradient: importance of competition and energetic constraint. Ecology 78: 1502-1518

Barbraud C, Weimerskirch H (2003) Climate and density shape population dynamics of a marine top predator. Proc Biol Sci 270:2111-2116

Barbraud C, Delord K, Marteau C, Weimerskirch H (2009) Estimates of population size of white-chinned petrels and grey petrels at Kerguelen Islands and sensitivity to fisheries. Anim Conserv 12:258-265

Barrett RT, Camphuysen CJ, Anker-Nilssen T, Chardine JW and others (2007) Diet studies of seabirds: a review and recommendations. ICES J Mar Sci 64:1675-1691

Bartle JA (1991) Incidental capture of seabirds in the New Zealand subantarctic squid trawl fishery, 1990. Bird Conserv Int 1:351-359

> Bartumeus F, Giuggioli L, Louzao M, Bretagnolle V, Oro D, Levin S (2010) Fishery discards impact on seabird movement patterns at regional scales. Curr Biol 20:215-222

Baum JK, Worm B (2009) Cascading top-down effects of changing oceanic predator abundances. J Anim Ecol 78: 699-714

> Behrenfeld MJ, Falkowski PG (1997) Photosynthetic rates derived from satellite-based chlorophyll concentration. Limnol Oceanogr 42:1-20

> Behrenfeld MJ, O'Malley RT, Siegel DA, McClain CR and others (2006) Climate-driven trends in contemporary ocean productivity. Nature 444:752-755

- Berrow SD, Croxall JP (1999) The diet of white-chinned petrels Procellaria aequinoctialis, Linnaeus 1758, in years of contrasting prey availability at South Georgia. Antarct Sci 11:283-292

> Bertram DF, Harfenist A, Smith BD (2005) Ocean climate and El Niño impacts on survival of Cassin's auklets from upwelling and downwelling domains of British Columbia. Can J Fish Aquat Sci 62:2841-2853

BirdLife International (2004) Tracking ocean wanderers: the global distribution of albatrosses and petrels. Results from the Global Procellariiform Tracking Workshop, 1-5 September, 2003, Gordon's Bay, South Africa. BirdLife International, Cambridge

- Birkhead TR (1977) The effect of habitat and density on breeding success in the common guillemot (Uria aalge). J Anim Ecol 46:751-764

> Boersma PD, Parrish JK (1999) Limiting abuse: marine protected areas, a limited solution. Ecol Econ 31:287-304

Boersma PD, Clark JA, Hillgarth N (2002) Seabird conservation. In: Schreiber EA, Burger J (eds) Biology of marine birds. CRC Press, Boca Raton, FL, p 559-580

> Boessenkool S, Star B, Waters JM, Seddon PJ (2009) Multilocus assignment analyses reveal multiple units and rare migration events in the recently expanded yellow-eyed penguin (Megadyptes antipodes). Mol Ecol 18: 2390-2400

Boggs CH (2001) Deterring albatrosses from contacting baits during swordfish longline sets. In: Melvin E, Parrish K (eds) Seabird bycatch: trends, roadblocks, and solutions. University of Alaska, Fairbanks, AK, p 79-94

Bonnaud E, Bourgeois K, Vidal E, Legrand J, Le Corre M (2009) How can the Yelkouan shearwater survive feral 
cat predation? A meta-population structure as a solution. Popul Ecol 51:261-270

Bost CA, Jaeger A, Huin W, Koubbi P, Halsey LG, Hanuise N, Handrich Y (2008) Monitoring prey availability via data loggers deployed on seabirds: advances and present limitations. In: Tsukamoto $K$, Kawamura $T$, Takeuchi, T, Beard TD Jr, Kaiser MD (eds) Fisheries for global welfare and environment. 5th World Fisheries Congress 2008, Yokohama, p 121-137

> Bost CA, Cotté C, Bailleul F, Cherel Y and others (2009) The importance of oceanographic fronts to marine birds and mammals of the southern oceans. J Mar Syst 78:363-376

Boulinier T, Lemel JY (1996) Spatial and temporal variations of factors affecting breeding habitat quality in colonial birds: some consequences for dispersal and habitat selection. Acta Oecol 17:531-552

Bourgeois K, Vidal E (2007) Yelkouan shearwater nest-cavity selection and breeding success. C R Biol 330:205-214

Briggs KT, Tyler WB, Lewis DB, Carlson DR (1987) Bird communities at sea off California: 1975-1983. Studies Avian Biol 11, Cooper Ornithological Society, Berkeley, CA

> Brooke MdeL, O'Connell TC, Wingate D, Madeiros J, Hilton GM, Ratcliffe N (2010) The potential for rat predation to cause decline of the globally threatened Henderson petrel Pterodroma atrata: evidence from the field, stable isotopes and population modelling. Endang Species Res 11:47-59

Brothers N (1991) Albatross mortality and associated bait loss in the Japanese longline fishery in the Southern Ocean. Biol Conserv 55:255-268

Brothers NP, Reid TA, Gales RP (1997) At-sea distribution of shy albatrosses Diomedea cauta cauta derived from records of band recoveries and colour-marked birds. Emu 97:231-239

Brothers NP, Cooper J, Løkkeborg S (1999) The incidental catch of seabirds by longline fisheries: worldwide review and technical guidelines for mitigation. Fisheries Circular 937, Food and Agriculture Organization, Rome

Brown RGB, Cooke F, Kinnear PK, Mills EL (1975) Summer seabird distribution in the Drake Passage, Chilean fjords and off southern South America. Ibis 117:339-356

$>$ Bryant R, Jones IL (1999) Food resource use and diet overlap of common and thick-billed murres at the Gannet Islands, Labrador. Waterbirds 22:392-400

> Buckland ST, Marsden SJ, Green RE (2008) Estimating bird abundance: making methods work. Bird Conserv Int 18: S91-S108

Bullock JM, Kenward RE, Hails RS (2002) Dispersal ecology. Cambridge University Press, Cambridge

- Bunce A, Norman F, Brothers N, Gales R (2002) Long-term trends in the Australian gannet (Morus serrator) population in Australia: the effect of climate change and commercial fisheries. Mar Biol 141:263-269

Bundy A (2005) Structure and functioning of the eastern Scotian Shelf ecosystem before and after the collapse of groundfish stocks in the early 1990s. Can J Fish Aquat Sci 62:1453-1473

Burg TM (2007) Genetic analysis of wandering albatrosses killed in longline fisheries off the east coast of New Zealand. Aquat Conserv: Mar Freshw Ecosyst 17: S93-S101

Burger J, Gochfeld M (2002) Effects of chemicals and pollution on seabirds. In: Schreiber E, Burger J (eds) Biology of marine birds. CRC Press, Boca Raton, FL, p 485-524
Burger AE, Shaffer SA (2008) Perspectives in ornithology: application of tracking and data-logging technology in research and conservation of seabirds. Auk 125:253-264

Burson SL III (1990) Population genetics and gene flow of the common tern. Condor 92:182-192

Butchart SHM, Stattersfield AJ, Bennun LA, Shutes SM and others (2004) Measuring global trends in the status of biodiversity: Red List indices for birds. PLoS Biol 2:e383

> Cai W, Cowan T, Raupach M (2009) Positive Indian Ocean dipole events precondition southeast Australia bushfires. Geophys Res Lett 36:L19710. doi:10.1029/2009GL039902

Cairns DK (1987) Seabirds as indicators of marine food supplies. Biol Oceanogr 5:261-271

Cam E, Oro D, Pradel R, Jimenez JE (2004) Assessment of hypotheses about dispersal in a long-lived seabird using multistate capture-recapture models. J Anim Ecol 73:723-736

> Camphuysen CJ, Garthe S (1997) An evaluation of the distribution and scavenging habits of northern fulmars (Fulmarus glacialis) in the North Sea. ICES J Mar Sci 54: 654-683

Caswell H (2001) Matrix population models: construction, analysis, and interpretation. Sinauer, Sunderland, MA

Catry T, Ramos JA, Jaquemet S, Faulquier L, Berlincourt M, Pinet P, Le Corre M (2009) Comparative foraging ecology of a tropical seabird community of the Seychelles, western Indian Ocean. Mar Ecol Prog Ser 374:259-272

> Chapman EW, Ribic CA, Fraser WR (2004) The distribution of seabirds and pinnipeds in Marguerite Bay and their relationship to physical features during austral winter 2001. Deep-Sea Res II 51:2261-2278

Cherel Y, Hobson KA (2007) Geographical variation in carbon stable isotope signatures of marine predators: a tool to investigate their foraging areas in the Southern Ocean. Mar Ecol Prog Ser 329:281-287

> Cherel Y, Weimerskirch H, Duhamel G (1996) Interactions between longline vessels and seabirds in Kerguelen waters and a method to reduce seabird mortality. Biol Conserv 75:63-70

Cherel Y, Hobson KA, Weimerskirch H (2005) Using stable isotopes to study resource acquisition and allocation in procellariiform seabirds. Oecologia 145:533-540

> Christensen JT, Richardson R (2008) Stable isotope evidence of long-term changes in the North Sea food web structure. Mar Ecol Prog Ser 368:1-8

$>$ Clark JS (2005) Why environmental scientists are becoming Bayesians. Ecol Lett 8:2-14

Clobert J, Danchin E, Dhondt A, Nichols JD (2001) Dispersal. Oxford University Press, Oxford

Coad L, Burgess ND, Loucks C, Fish L, Scharlemann JPW, Duarte L, Besançon B (2009) The ecological representativeness of the global protected areas estate in 2009: progress towards the CBD 2010 target. UNEP-WCMC, WWF-US and ECI, University of Oxford. http://www. unep-wcmc.org/medialibrary/2010/09/24/a9872b15/ Global_Ecoregions.pdf

> Cody ML (1973) Coexistence, coevolution and convergent evolution in seabird communities. Ecology 54:31-44

> Connan M, Cherel Y, Mayzaud P (2007) Lipids from stomach oil of procellariiform seabirds document the importance of myctophid fish in the Southern Ocean. Limnol Oceanogr 52:2445-2455

Converse SJ, Kendall WL, Doherty PF Jr, Ryan PG, Johnson DH (2009) Multistate models for estimation of survival and reproduction in the grey-headed albatross (Thalassarche chrysostoma). Auk 126:77-88 
Coulson JC (1991) The population dynamics of culling herring gulls and lesser black-backed gulls. In: Perrins CM, Lebreton JD, Hirons GJM (eds) Bird population studies: relevance to conservation and management. Oxford University Press, Oxford, p 479-497

Courchamp F, Chapuis JL, Pascal M (2003) Mammal invaders on islands: impact, control and control impact. Biol Rev Camb Philos Soc 78:347-383

Cousins KL (2001) The black-footed albatross population biology workshop: a step to understanding the impacts of longline fishing on seabird populations. In: Melvin E, Parrish J (eds) Seabird bycatch: trends, roadblocks, and solutions. University of Alaska Sea Grant, Anchorage, AK, p 95-114

> Cox TM, Lewison RL, Zydelis R, Crowder LB, Safina C, Read AJ (2007) Comparing effectiveness of experimental and implemented bycatch reduction measures: the ideal and the real. Conserv Biol 21:1155-1164

Croxall JP (2008) Seabird mortality and trawl fisheries. Anim Conserv 11:255-256

Croxall JP, Prince PA (1990) Recoveries of wandering albatrosses Diomedea exulans ringed at South Georgia, 1958-1986. Ring Migr 11:43-51

Croxall JP, Reid K, Prince PA (1999) Diet, provisioning and productivity responses of marine predators to differences in availability of Antarctic krill. Mar Ecol Prog Ser 177: 115-131

> Cury P, Bakun A, Crawford RJM, Jarre A, Quinones RA, Shannon LJ, Verheye HM (2000) Small pelagics in upwelling systems: patterns of interaction and structural changes in wasp-waist ecosystems. ICES J Mar Sci 57:603-618

> Cuthbert R, Hilton G (2004) Introduced house mice Mus musculus: a significant predator of threatened and endemic birds on Gough Island, South Atlantic Ocean? Biol Conserv 117:483-489

- Danchin E, Wagner R (1997) The evolution of coloniality: the emergence of new perspectives. Trends Ecol Evol 12: 342-347

> Danchin E, Boulinier T, Massott M (1998) Conspecific reproductive success and breeding habitat selection: implications for the study of coloniality. Ecology 79:2415-2428

> Davoren GK, Montevecchi WA, Anderson JT (2003) Search strategies of a pursuit-diving marine bird and the persistence of prey patches. Ecol Monogr 73:463-481

- Dearborn DC, Anders AD, Schreiber EA, Adams RMM, Mueller UG (2003) Inter-island movements and population differentiation in a pelagic seabird. Mol Ecol 12: 2835-2843

Devney CA, Short M, Congdon BC (2009) Sensitivity of tropical seabirds to El Niño precursors. Ecology 90:1175-1183

Diamond AW, Schreiber EA (2002) Magnificent frigatebird (Fregata magnificens). In: Poole A (ed) The birds of North America No. 601. Online Cornell Lab of Ornithology, Ithaca, NY. http://bna.birds.cornell.edu/bna/species/ 601

> Dieckmann U, O'Hara B, Weisser W (1999) The evolutionary ecology of dispersal. Trends Ecol Evol 14:88-90

$>$ Doherty J Jr, Schreiber EA, Nichols JD, Hines JE, Link WA, Schenk GA, Schreiber RW (2004) Testing life history predictions in a long-lived seabird: a population matrix approach with improved parameter estimation. Oikos 105:606-618

> Doligez B, Gustafsson L, Pärt T (2009) 'Heritability' of dispersal propensity in a patchy population. Proc Biol Sci 276:2829-2836
Durant JM, Stenseth NC, Anker-Nilssen T, Harris MP, Thompson PM, Wanless S (2004) Marine birds and climate fluctuations in the North Atlantic. In: Stenseth NC, Ottersen G, Hurrell JW, Belgrano A (eds) Marine ecosystems and climate variation: the North Atlantic - a comparative perspective. Oxford University Press, Oxford, p 95-105

- Durant JM, Hjermann DØ, Frederiksen M, Charrassin JB and others (2009) Pros and cons of using seabirds as ecological indicators. Clim Res 39:115-129

Edwards SV, Silva MC, Burg T, Friesen V, Warheit KI (2001) Molecular genetic markers in the analysis of seabird bycatch populations. In: Melvin E, Parrish JK (eds) Seabird bycatch: trends, roadblocks and solutions. Washington and Alaska Sea Grant, Anchorage, AK, p 115-140

Egevang C, Stenhouse IJ, Phillips RA, Petersen A, Fox JW, Silk JRD (2010) Tracking of Arctic terns Sterna paradisaea reveals longest animal migration. Proc Natl Acad Sci USA 107:2078-2081

Ehler C, Douvere F (2009) Marine spatial planning: a stepby-step approach toward ecosystem-based management. Intergovernmental Oceanographic Commission and Man and the Biosphere Programme. IOC Manual and Guides No. 53, IOCAM Dosier No. 6, UNESCO, Paris

> Engen S, Lande R, Sæether BE, Weimerskirch H (2005) Extinction in relation to demographic and environmental stochasticity in age-structured models. Math Biosci 195: 210-227

- Enstipp MR, Grémillet D, Jones DR (2007) Investigating the functional link between prey abundance and seabird predatory performance. Mar Ecol Prog Ser 331:267-279

Esparza B, Martínez-Abraín A, Merino S, Oro D (2004) Immunocompetence and the prevalence of haematozoan parasites in two long-lived seabirds. Ornis Fenn 81: $40-46$

Estes J, Demaster D, Doak D, Williams T, Brownell R (2006) Whales, whaling, and ocean ecosystems. University of California Press, Berkeley, CA

- Ezard THG, Becker PH, Coulson T (2006) The contributions of age and sex to variation in common tern population growth rate. J Anim Ecol 75:1379-1386

Fauchald P (2009) Spatial interactions between seabirds and prey: review and synthesis. Mar Ecol Prog Ser 391: 139-151

Finkelstein M, Keitt BS, Croll DA, Tershy B and others (2006) Albatross species demonstrate regional differences in North Pacific marine contamination. Ecol Appl 16:678-686

Finkelstein ME, Doak DF, Nakagawa M, Sievert PR, Klavitter J (2010) Assessment of demographic risk factors and management priorities: impacts on juveniles substantially affect population viability of a long-lived seabird. Anim Conserv 13:148-156

Flint PL, Fowler AC, Rockwell RF (1999) Modeling bird mortality associated with the M/V Citrus oil spill off St. Paul Island, Alaska. Ecol Model 117:261-267

Forero MG, Bortolotti GR, Hobson KA, Donazar JA, Bertellotti M, Blanco G (2004) High trophic overlap within the seabird community of Argentinean Patagonia: a multiscale approach. J Anim Ecol 73:789-801

Fort J, Porter WP, Grémillet D (2009) Thermodynamic modelling predicts energetic bottleneck for seabirds wintering in the northwest Atlantic. J Exp Biol 212:2483-2490 
Frank KT, Petrie B, Choi JS, Leggett WC (2005) Trophic cascades in a formerly cod-dominated ecosystem. Science 308:1621-1623

Frederiksen M, Wanless S, Harris MP, Rothery P, Wilson LJ (2004) The role of industrial fisheries and oceanographic change in the decline of North Sea black-legged kittiwakes. J Appl Ecol 41:1129-1139

Frederiksen M, Furness RW, Wanless S (2007) Regional variation in the role of bottom-up and top-down processes in controlling sandeel abundance in the North Sea. Mar Ecol Prog Ser 337:279-286

Frederiksen M, Daunt F, Harris MP, Wanless S (2008) The demographic impact of extreme events: stochastic weather drives survival and population dynamics in a long-lived seabird. J Anim Ecol 77:1020-1029

Friesen VL, González JA, Cruz-Delgado F (2006) Population genetic structure and conservation of the Galápagos petrel (Pterodroma phaeopygia). Conserv Genet 7: 105-115

Friesen VL, Burg TM, McCoy KD (2007) Mechanisms of population differentiation in seabirds. Mol Ecol 16: 1765-1785

Furness RW (1993) Birds as monitors of pollutants. In: Furness RW, Greenwood JJD (eds) Birds as monitors of environmental change. Chapman \& Hall, London, p 86-143

Furness RW (2000) Impacts of fisheries on seabird community stability. ICES Annual Science Conference, Bruges, 27-30 September 2000. www.ices.dk/products/CMdocs/ 2000/Q/Q0300.pdf

Furness RW (2003) Impacts of fisheries on seabird communities. Sci Mar 67:33-45

> Furness RW, Barrett RT (1985) The food requirements and ecological relationships of a seabird community in north Norway. Ornis Scand 16:305-313

Furness RW, Birkhead TR (1984) Seabird colony distributions suggest competition for food supplies during the breeding season. Nature 311:655-656

Furness RW, Camphuysen CJK (1997) Seabirds as monitors of the marine environment. ICES J Mar Sci 54:726-737

Furness RW, Monaghan P (1987) Seabird ecology. Blackie, Glasgow

Furness RW, Ensor K, Hudson AV (1992) The use of fishery waste by gull populations around the British Isles. Ardea 80:105-113

> Game ET, Grantham HS, Hobday AJ, Pressey RL and others (2009) Pelagic protected areas: the missing dimension in ocean conservation. Trends Ecol Evol 24:360-369

García Borboroglu P, Yorio P (2007) Comparative habitat use by syntopic kelp gulls (Larus dominicanus) and Olrog's gulls (L. atlanticus) in coastal Patagonia. Emu 107: 321-326

> Garthe S, Camphuysen CJK, Furness RW (1996) Amounts of discards by commercial fisheries and their significance as food for seabirds in the North Sea. Mar Ecol Prog Ser 136:1-11

Gaston KJ, Chown SL, Calosi P, Bernardo J and others (2009) Macrophysiology: a conceptual reunification. Am Nat 174:595-612

Genovart M, Oro D, Bonhomme F (2003) Genetic and morphological differentiation between breeding colonies of Audouin's gull Larus audouinii. Ibis 145:448-456

Genovart M, Oro D, Juste J, Bertorelle G (2007) What genetics tell us about the conservation of the critically endangered Balearic shearwater? Biol Conserv 137:283-293
Gilchrist HG (1999) Declining thick-billed murre Uria lomvia colonies experience higher gull predation rates: an inter-colony comparison. Biol Conserv 87:21-29

Gilman E, Brothers N, Kobayashi DR (2005) Principles and approaches to abate seabird by-catch in longline fisheries. Fish Fish 6:35-49

> Gimenez O, Viallefont A, Charmantier A, Pradel R and others (2008) The risk of flawed inference in evolutionary studies when detectability is less than one. Am Nat 172: 441-448

Gómez-Díaz E, González-Solís J (2007) Geographic assignment of seabirds to their origin: combining morphologic, genetic, and biogeochemical analyses. Ecol Appl 17: 1484-1498

> González-Solís J, Shaffer SA (2009) Introduction and synthesis: spatial ecology of seabirds at sea. Mar Ecol Prog Ser 391:117-120

> González-Solís J, Croxall JP, Wood AG (2000) Foraging partitioning between giant petrels Macronectes spp. and its relationship with breeding population changes at Bird Island, South Georgia. Mar Ecol Prog Ser 204:279-288

> González-Solís J, Croxall JP, Oro D, Ruiz X (2007) Transequatorial migration and mixing in the wintering areas of a pelagic seabird. Front Ecol Environ 5:297-301

> González-Solís J, Felicísimo A, Fox JW, Afanasyev V, Kolbeinsson Y, Moñoz J (2009) Influence of sea surface winds on shearwater migration detours. Mar Ecol Prog Ser 391:221-230

Grandgeorge M, Wanless S, Dunn TE, Maumy M, Beaugrand G, Grémillet D (2008) Resilience of the British and Irish seabird community in the twentieth century. Aquat Biol 4:187-199

Green RE (1995) Diagosing causes of bird population declines. Ibis 137:S47-S55

> Grémillet D, Boulinier T (2009) Spatial ecology and conservation of seabirds facing global climate change: a review. Mar Ecol Prog Ser 391:121-137

Grémillet D, Charmantier A (2010) Shifts in phenotypic plasticity constraint the value of seabirds as ecological indicators of marine ecosystems. Ecol Appl 20:1498-1503

Grémillet D, Dell'Omo G, Ryan PG, Peters G, Ropert-Coudert Y, Weeks S J (2004) Offshore diplomacy, or how seabirds mitigate intra-specific competition: a case study based on GPS tracking of Cape gannets from neighbouring colonies. Mar Ecol Prog Ser 268:265-279

Grémillet D, Lewis S, Drapeau L, van der Lingen CD and others (2008) Spatial match-mismatch in the Benguela upwelling zone: Should we expect chlorophyll and SST to predict marine predator distributions? J Appl Ecol 45: $610-621$

> Grimm V, Revilla E, Groeneveld J, Kramer-Schadt S and others (2005) Importance of buffer mechanisms for population viability analysis. Conserv Biol 19:578-580

Grosbois V, Thompson PM (2005) North Atlantic climate variation influences survival in adult fulmars. Oikos 109: 273-290

Grosbois V, Harris MP, Anker-Nilssen T, McCleery RH, Shaw DN, Morgan BJT, Gimenez O (2009) Modeling survival at multi-population scales using mark-recapture data. Ecology 90:2922-2932

Gubbay S (2004) A review of marine environmental indicators reporting on biodiversity aspects of ecosystem health. The Royal Society for the Protection of Birds, Sandy. www.rspb.org.uk/Images/Indicators_tcm9-132910. pdf 
Guisan A, Thuiller W (2005) Predicting species distribution: offering more than simple habitat models. Ecol Lett 8: 993-1009

Halpern BS, Walbridge S, Selkoe KA, Kappel CV and others (2008) A Global map of human impact on marine ecosystems. Science 319:948-952

Halpin PN, Read AJ, Fujioka E, Best BD and others (2009) OBIS-SEAMAP: the world data center for marine mammal, sea bird, and sea turtle distributions. Oceanography (Wash DC) 22:104-115

Hamann M, Godfrey MH, Seminoff JA, Arthur K and others (2010) Global research priorities for sea turtles: informing management and conservation in the 21st century. Endang Species Res 11:245-269

> Hamer KC (2010) The search for winners and losers in a sea of climate change. Ibis 152:3-5

> Hamer KC, Furness RW, Caldow RWG (1991) The effects of changes in food supply on the breeding ecology of great skuas Catharacta skua in Shetland. J Zool (Lond) 223: 175-188

Hamer KC, Schreiber EA, Burger J (2002) Breeding biology, life histories, and life history-environment interactions in seabirds. In: Schreiber EA, Burger J (eds) Biology of marine birds. CRC Press, Boca Raton, FL, p 217-261

> Hamer KC, Humphreys EM, Garthe S, Hennicke J and others (2007) Annual variation in diets, feeding locations and foraging behavior of gannets in the North Sea: flexibility, consistency and constraint. Mar Ecol Prog Ser 338:295-305

Haney JC (1985) Counting seabirds at sea from ships: comments on interstudy comparisons and methodological standardization. Auk 102:897-898

Hanski I, Gaggiotti OE (2004) Ecology, genetics, and evolution of metapopulations. Academic Press, San Diego, CA

Harley CDG, Hughes AR, Hultgren KM, Miner BG and others (2006) The impacts of climate change in coastal marine systems. Ecol Lett 9:228-241

Harris MP, Wanless S (1996) Differential responses of guillemot Uria aalge and shag Phalacrocorax aristotelis to a late winter wreck. Bird Study 43:220-230

> Harrison CS (1982) Spring distribution of marine birds in the Gulf of Alaska. Condor 84:245-254

> Hart KM, Hyrenbach KD (2009) Satellite telemetry of marine megavertebrates: the coming of age of an experimental science. Endang Species Res 10:9-20

Hatch JJ, Weseloh DV (1999) Double-crested cormorant (Phalacrocorax auritus). In: Poole A, Gill F (eds) The birds of North America, No. 441. The Birds of North America, Inc., Philadelphia, PA

Hawke DJ, Clark JMcK (2010) Incorporation of the invasive mallow Lavatera arborea into the food web of an active seabird island. Biol Invasions 12:1805-1814

Hedrick PW (2001) Conservation genetics: Where are we now? Trends Ecol Evol 16:629-636

Heino M, Kaitala V, Ranta E, Lindström J (1997) Synchronous dynamics and rates of extinction in spatially structured populations. Proc Biol Sci 264:481-486

Heithaus MR, Frid A, Wirsing AJ, Worm B (2008) Predicting ecological consequences of marine top predator declines. Trends Ecol Evol 23:202-210

Hilborn R, Branch TA, Ernst B, Magnusson A, Minte-Vera CV, Scheuerell MD, Valero JL (2003) State of the world's fisheries. Annu Rev Environ Resour 28:359-399

Hooker S, Gerber LR (2004) Potential importance of megafauna: marine reserves as a tool for ecosystem-based management? Bioscience 54:27-41
Howes LA, Montevecchi WA (1993) Population trends and interactions among terns and gulls in Gros Morne National Park, Newfoundland. Can J Zool 71: 1516-1520

> Hunt GL (1991) Occurrence of polar seabirds at sea in relation to prey concentrations and oceanographic factors. Polar Res 10:553-559

Hunt GL, Schneider DC (1987) Scale-dependent processes in the marine environment. In: Croxall JP (ed) Seabirds feeding ecology and role in marine ecosystems. Cambridge University Press, Cambridge, p 7-43

Hunt GL Jr, Harrison NM, (1990) Foraging habitat and prey taken by least auklets at King Island, Alaska. Mar Ecol Prog Ser 65:141-150

> Hunt GL Jr, Stabeno P, Walters G, Sinclair E, Brodeur RD, Napp JM, Bond NA (2002) Climate change and control of the southeastern Bering Sea pelagic ecosystem. DeepSea Res II 49:5821-5853

Huntley B, Green RE, Collingham YC, Willis SG (2007) A climatic atlas of European breeding birds. Durham University, The RSPB and Lynx Edicions, Barcelona

Hyrenbach KD, Forney KA, Dayton PK (2000) Marine protected areas and ocean basin management. Aquat Conserv: Mar Freshw Ecosyst10:437-458

> Hyrenbach KD, Veit RR, Weimerskirch H, Hunt GL (2006) Seabird associations with mesocale eddies: the subtropical Indian Ocean. Mar Ecol Prog Ser 324:271-279

> Igual JM, Forero MG, Gomez T, Orueta JF, Oro D (2006) Rat control and breeding performance in Cory's shearwater (Calonectris diomedea): effects of poisoning effort and habitat features. Anim Conserv 9:59-65

Igual JM, Forero MG, Gomez T, Oro D (2007) Can an introduced predator trigger an evolutionary trap in a colonial seabird? Biol Conserv 137:189-196

Inchausti P, Weimerskirch H (2002) Dispersal and metapopulation dynamics of an oceanic seabird, the wandering albatross, and its consequences for its response to longline fisheries. J Anim Ecol 71:765-770

Irons DB, Anker-Nilssen T, Gaston AJ, Byrd GV and others (2008) Fluctuations in circumpolar seabird populations linked to climate oscillations. Glob Change Biol 14: 1455-1463

> Jackson JBC, Kirby MX, Berger WH, Bjorndal KA and others (2001) Historical overfishing and the recent collapse of coastal ecosystems. Science 293:629-637

Jaquemet S, Le Corre M, Marsac F, Potier M, Weimerskirch $\mathrm{H}$ (2005) Foraging habitats of the seabird community of Europa Island (Mozambique Channel). Mar Biol 147: 573-582

Jenouvrier S, Barbraud C, Cazelles B, Weimerskirch H (2005a) Modelling population dynamics of seabirds: importance of the effects of climate fluctuations on breeding proportions. Oikos 108:511-522

Jenouvrier S, Barbraud C, Weimerskirch H (2005b) Longterm contrasted responses to climate of two Antarctic seabird species. Ecology 86:2889-2903

Jenouvrier S, Tavecchia G, Thibault JC, Choquet R, Bretagnolle V (2008) Recruitment processes in long-lived species with delayed maturity: estimating key demographic parameters. Oikos 117:620-628

> Jovani R, Mavor R, Oro D (2008) Hidden patterns of colony size variation: a logarithmic point of view. Oikos 117 : 1774-1781

Käkelä A, Furness RW, Kelly A, Strandberg U, Waldron S, Käkelä R (2007) Fatty acid signatures and stable isotopes 
as dietary indicators in North Sea seabirds. Mar Ecol Prog Ser 342:291-301

Käkelä R, Käkelä A, Martínez-Abraín A, Sarzo B and others (2010) Fatty acid signature analysis confirms foraging resources of a globally endangered Mediterranean seabird species: calibration test and application to the wild. Mar Ecol Prog Ser 398:245-258

> Karpouzi VS, Watson R, Pauly D (2007) Modelling and mapping resource overlap between seabirds and fisheries on a global scale: a preliminary assessment. Mar Ecol Prog Ser 343:87-99

Kelleher K (2004) Discards in the world's marine fisheries: an update. FAO Fish Tech Pap 470:1-131

> Kendall WL, Converse SJ, Doherty PF, Naughton MB, Anders A, Hines JE, Flint E (2009) Sampling design considerations for demographic studies: a case of colonial seabirds. Ecol Appl 19:55-68

- Kitaysky AS, Golubova EG (2000) Climate change causes contrasting trends in reproductive performance of planktivorous and piscivorous alcids. J Anim Ecol 69: 248-262

Kitaysky AS, Kitaiskaia EV, Piatt JF, Wingfield JC (2006) A mechanistic link between chick diet and decline in seabirds. Proc Biol Sci 273:445-450

Koenig WD, Van Vuren D, Hooge PN (1996) Detectability, philopatry, and the distribution of dispersal distances in vertebrates. Trends Ecol Evol 11:514-517

Kubiak TJ, Harris HJ, Smith LM, Schwartz TR and others (1989) Microcontaminants and reproductive impairment of the Forster's tern on Green Bay, Lake Michigan-1983. Arch Environ Contam Toxicol 18:706-727

> Laneri K, Louzao M, Martínez-Abraín A, Arcos JM and others (2010) Trawling regime influences longline seabird bycatch in the Mediterranean: new insights from a smallscale fishery. Mar Ecol Prog Ser 420:241-252

- Lawrence HA, Taylor GA, Crockett DE, Millar CD, Lambert DM (2008) New genetic approach to detecting individuals of rare and endangered species. Conserv Biol 22: 1267-1276

> Le Bohec C, Durant JM, Gauthier-Clerc M, Stenseth NC and others (2008) King penguin population threatened by Southern Ocean warming. Proc Natl Acad Sci USA 105: 2493-2497

Lebreton JD, Hines JE, Pradel R, Nichols JD, Spendelow JA (2003) Estimation by capture-recapture of recruitment and dispersal over several sites. Oikos 101:253-264

Lebreton JD, Nichols JD, Barker R, Pradel R, Spendelow J (2009) Modeling individual animal histories with multistate capture-recapture models. Adv Ecol Res 41:87-173

Levins R (1970) Extinction. In: Gerstenhaber M (ed) Some mathematical problems in biology. American Mathematical Society, Providence, RI, p 77-107

Lewison RL, Nel D, Taylor F, Croxall JP, Rivera K (2005) Thinking big-taking a large-scale approach to seabird bycatch. Mar Ornithol 33:1-5

Lipcius RN, Crowder LB, Morgan LE (2005) Metapopulation structure and marine reserves. In: Norse E, Crowder LB (eds) Marine conservation biology. Island Press, Washington, DC, p 328-345

- Lloret J, Palomera I, Salat J, Solé I (2004) Impact of freshwater input and wind on landings of anchovy (Engraulis encrasicolus) and sardine (Sardina pilchardus) in shelf waters surrounding the Ebre River delta (northwestern Mediterranean). Fish Oceanogr 13:102-110

> Louzao M, Hyrenbach KD, Arcos JM, Abello P, De Sola LG,
Oro D (2006) Oceanographic habitat of an endangered Mediterranean procellariiform: implications for marine protected areas. Ecol Appl 16:1683-1695

Louzao M, Bécares J, Rodríguez B, Hyrenbach KD, Ruiz A, Arcos JM (2009) Combining vessel-based surveys and tracking data to identify key marine areas for seabirds. Mar Ecol Prog Ser 391:183-197

Lucas Z, MacGregor C (2006) Characterization and source of oil contamination on the beaches and seabird corpses, Sable Island, Nova Scotia, 1996-2005. Mar Pollut Bull 52: 778-789

Mace GM, Collar NJ, Gaston KJ, Hilton-Taylor C and others (2008) Quantification of extinction risk: IUCN's system for classifying threatened species. Conserv Biol 22: 1424-1442

Mantua NJ, Hare SR, Zhang Y, Wallace JM, Francis RC (1997) A Pacific interdecadal climate oscillation with impacts on salmon production. Bull Am Meteorol Soc 78: 1069-1079

> Marques TA, Thomas L, Fancy SG, Buckland ST (2007) Improving estimates of bird density using multiplecovariate distance sampling. Auk 124:1229-1243

Martin JL, Thibault JC, Bretagnolle V (2000) Black rats, island characteristics, and colonial nesting birds in the Mediterranean: consequences of an ancient introduction. Conserv Biol 14:1452-1466

> Martínez-Abraín A, Sarzo B, Villuendas E, Bartolomé MA, Minguez E, Oro D (2004) Unforeseen effects of ecosystem restoration on yellow-legged gulls in a small western Mediterranean island. Environ Conserv 31:219-224

Martínez-Abraín A, Velando A, Oro D, Genovart M and others (2006) Sex-specific mortality of European shags after the Prestige oil spill: demographic implications for the recovery of colonies. Mar Ecol Prog Ser 318:271-276

> Mateos M, Arroyo GM (2010) Ocean surface winds drive local-scale movements within long-distance migrations of seabirds. Mar Biol 158:329-339

> McCoy KD, Boulinier T, Tirard C (2005a) Comparative hostparasite population structures: disentangling prospecting and dispersal in the black-legged kittiwake Rissa tridactyla. Mol Ecol 14:2825-2838

McCoy KD, Chapuis E, Tirard C, Boulinier T and others (2005b) Recurrent evolution of host-specialized races in a globally-distributed parasite. Proc R Soc Lond B Biol Sci 272:2389-2395

> MEA (Millennium Ecosystem Assessment) (2005) Ecosystems and human well-being. Biodiversity Synthesis World Resources Institute, Washington, DC

Melvin E, Parrish J, Conquest L (1999) Novel tools to reduce seabird bycatch in coastal gillnet fisheries. Conserv Biol 13:1386-1397

Melvin EF, Parrish JK, Dietrich KS, Hamel OS (2001) Solutions to seabird bycatch in Alaska's demersal longline fisheries. Washington Sea Grant Program, Seattle, WA

Melvin EF, Sullivan B, Robertson G, Weinecke B (2004) A review of the effectiveness of streamer lines as a seabird by-catch mitigation technique in longline fisheries and CCAMLR streamer lines requirements. CCAMLR Science 11:189-201

Mills MSL, Ryan PG (2005) Modelling impacts of long-line fishing: What are the effects of pair-bond disruption and sex-biased mortality on albatross fecundity? Anim Conserv 8:359-367

Milot E, Weimerskirch H, Bernatchez L (2008) The seabird paradox: dispersal, genetic structure and population 
dynamics in a highly mobile, but philopatric albatross species. Mol Ecol 17:1658-1673

Moloney CL, Cooper J, Ryan PG, Siegfried WR (1994) Use of a population model to assess the impact of longline fishing on wandering albatross Diomedea exulans populations. Biol Control 70:195-203

Montevecchi WA (2001) Seabirds as indicators of ocean pollution. In: Steele J, Thorpe S, Turekian K (eds) Encyclopedia of Ocean Sciences. Academic Press, London, p 2686-2690

Montevecchi WA (2012) Seabird capitals: the seabird Ecological Reserves of Newfoundland and Labrador. Flanker Press, St. John's

Montevecchi WA, Myers RA (1995) Prey harvests of seabirds reflect pelagic fish and squid abundance on multiple spatial and temporal scales. Mar Ecol Prog Ser 117:1-9

Montevecchi WA, Tuck LM (1987) Newfoundland birds: exploitation, study, conservation. Nuttall Ornithological Club, Cambridge, MA

$>$ Munilla I, Díez C, Velando A (2007) Are edge bird populations doomed to extinction? A retrospective analysis of the common guillemot collapse in Iberia. Biol Conserv 137:359-371

Murphy RC (1923) The oceanography of the Peruvian littoral with reference to the abundance and distribution of marine life. Geogr Rev 13:64-85

Murray TE, Bartle JA, Kalish SR, Taylor PR (1993) Incidental capture of seabirds in Japanese southern bluefin tuna longline vessels in New Zealand waters, 1988-1992. Bird Conserv Int 3:181-210

Mustin K, Sutherland WJ, Gill JA (2007) The complexity of predicting climate-induced ecological impacts. Clim Res 35:165-175

Navarro J, Louzao M, Igual JM, Oro D and others (2009) Seasonal changes in the diet of a critically endangered seabird and the importance of trawling discards. Mar Biol 156:2571-2578

> Navarro J, Oro D, Bertolero A, Genovart M, Delgado A, Forero MG (2010) Age and sexual differences in the exploitation of two anthropogenic trophic resources for an opportunistic seabird. Mar Biol 157:2453-2459

Nel DC, Ryan PG, Watkins BP (2002) Seabird mortality in the Patagonian toothfish longline fishery around the Prince Edward Islands, 1996-2000. Antarct Sci 14:151-161

- Nevitt GA, Bonadonna F (2005) Seeing the world through the nose of a bird: new developments in the sensory ecology of procellariiform seabirds. Mar Ecol Prog Ser 287: 292-295

Nicol S, Bowie A, Jarman S, Lannuzel D, Meiners KM, van der Merwe P (2010) Southern Ocean iron fertilization by baleen whales and Antarctic krill. Fish Fish 11:203-209

Nisbet ICT (2002) Common tern (Sterna hirundo). In: Poole A, Gill F (eds) The birds of North America. The Birds of North America, Inc., Philadelphia, PA

> Nogales M, Martin A, Tershy BR, Donlan CJ and others (2004) A review of feral cat eradication on islands. Conserv Biol 18:310-319

>'Toole D, Molloy J (2000) Preliminary performance assessment of an underwater line setting device for pelagic longline fishing. NZ J Mar Freshw Res 34:455-461

$>$ Olsson O, van der Jeugd HP (2002) Survival in king penguins Aptenodytes patagonicus: temporal and sex-specific effects of environmental variability. Oecologia 132: 509-516

> Oro D, Martínez-Abraín A (2007) Deconstructing myths on large gulls and their impact on threatened sympatric waterbirds. Anim Conserv 10:117-126

- Oro D, Pradel R, Lebreton JD (1999) Food availability and nest predation influence life history traits in Audouin's gull, Larus audouinii. Oecologia 118:438-445

Oro D, Cam E, Pradel R, Martínez-Abraín A (2004) Influence of food availability on demography and local population dynamics in a long-lived seabird. Proc R Soc Lond B Biol Sci 271:387-396

> Oro D, Martínez-Abraín A, Paracuellos M, Nevado JC, Genovart M (2006a) Influence of density-dependence on predator-prey seabird interactions at large spatio-temporal scales. Proc R Soc Lond B Biol Sci 273:379-383

Oro D, Tavecchia G, Pradel R (2006b) The role of recruitment in long-lived bird populations: the importance of a reliable estimation. J Ornithol 147:36-37

> Oro D, Pérez-Rodríguez A, Martínez-Vilalta A, Bertolero A, Vidal F, Genovart M (2009) Interference competition in a threatened seabird community: a paradox for successful conservation. Biol Conserv 142:1830-1835

Oro D, Torres R, Rodríguez C, Drummond H (2010) Climatic influence on demographic parameters of a tropical seabird varies with age and sex. Ecology 91:1205-1214

Orr JC, Fabry VJ, Aumont O, Bopp L and others (2005) Anthropogenic ocean acidification over the twenty-first century and its impact on calcifying organisms. Nature 437:681-686

> Österblom H, Hansson S, Larsson U, Hjerne O, Wulff F, Elmgren R, Folke C (2007) Human-induced trophic cascades and ecological regime shifts in the Baltic Sea. Ecosystems 10:877-889

Österblom H, Olsson O, Blenckner T, Furness RW (2008) Junk-food in marine ecosystems. Oikos 117:967-977

Oswald SA, Bearhop S, Furness RW, Huntley B, Hamer KC (2008) Heat stress in a high-latitude seabird: effects of temperature and food supply on bathing and nest attendance of great skuas. J Avian Biol 39:163-169

Ozgul A, Tuljapurkar S, Benton TG, Pemberton JM, Clutton-Brock TH, Coulson T (2009) The dynamics of phenotypic change and the shrinking sheep of St Kilda Science 325:464-467

Parrish JK, Bond N, Nevins H, Mantua N, Loeffel R, Peterson WT, Harvey JT (2007) Beached birds and physical forcing in the California Current System. Mar Ecol Prog Ser 352:275-288

Patterson TA, Thomas L, Wilcox C, Ovaskainen O, Matthiopoulos J (2008) State-space models of individual animal movement. Trends Ecol Evol 23:87-94

Pauly D (1995) Anecdotes and the shifting baseline syndrome of fisheries. Trends Ecol Evol 10:430

Pauly D, Maclean J (2003) In a perfect ocean: the state of fisheries and ecosystems in the North Atlantic. Ocean Island Press, Washington, DC

Pauly D, Christiansen V, Dalsgaard J, Froeser R, Torres F (1998) Fishing down marine food webs. Science 279: 860-863

Peery MZ, Beissinger SR, House RF, Berube M, Hall LA, Sellas A, Palsboll PJ (2008) Characterizing source-sink dynamics with genetic parentage assignments. Ecology 89:2746-2759

> Perry AL, Low PJ, Ellis JR, Reynolds JD (2005) Climate change and distribution shifts in marine fishes. Science 308:1912-1915

Peterson CH, Rice SD, Short JW, Esler D, Bodkin JL, Ballachey BE, Irons DB (2003) Long-term ecosystem 
response to the Exxon Valdez oil spill. Science 302: 2082-2086

Phillips RA, Silk JRD, Croxall JP (2005) Foraging and provisioning strategies of the light-mantled sooty albatross at South Georgia: competition and co-existence with sympatric pelagic predators. Mar Ecol Prog Ser 285:259-270

Phillips RA, Croxall JP, Silk JRD, Briggs DR (2007) Foraging ecology of albatrosses and petrels from South Georgia: two decades of insights from tracking technologies. Aquat Conserv Mar Freshw Ecosyst 17:S6-S21

Phillips RA, Ridley C, Reid K, Pugh PJA, Tuck GN, Harrison N (2010) Ingestion of fishing gear and entanglements of seabirds: monitoring and implications for management. Biol Conserv 143:501-512

Piatt JF, Nettleship DN, Threlfall W (1984) Net-mortality of common murres and Atlantic puffins in Newfoundland, 1951-81. In: Nettleship DN, Sanger GA, Springer PF (eds) Marine birds: their feeding ecology and commercial fisheries relationships. Supply and Services Canada, Ottawa, p 196-206

Piatt JF, Lensink CJ, Butler W, Kendziorek M, Nysewander DR (1990) Immediate impact of the Exxon Valdez oil spill on marine birds. Auk 107:387-397

Piatt JF, Harding AMA, Shultz M, Speckman SG, van Pelt TI, Drew GS, Kettle AB (2007) Seabirds as indicators of marine food supplies: Cairns revisited. Mar Ecol Prog Ser 352:221-234

> Pichegru L, Ryan PG, van der Lingen CD, Coetzee J, RopertCoudert Y, Grémillet D (2007) Foraging behavior and energetics of Cape gannets Morus capensis feeding on live prey in the Benguela upwelling system. Mar Ecol Prog Ser 350:127-136

> Pichegru L, Grémillet D, Crawford RJM, Ryan PG (2010) Marine no-take zone rapidly benefits endangered penguin. Biol Lett 6:498-501

Pitcher TJ (2001) Fisheries managed to rebuild ecosystems? Reconstructing the past to salvage the future. Ecol Appl 11:601-617

Pocklington R (1979) An oceanographic interpretation of seabird distributions in the Indian Ocean. Mar Biol 51: 9-21

Prince PA, Wood AG, Barton T, Croxall JP (1992) Satellite tracking of wandering albatrosses (Diomedea exulans) in the South Atlantic. Antarct Sci 4:31-36

Ramírez I, Geraldes P, Meirinho A, Amorim P, Paiva V (2008). Areas marinhas importantes para as aves em portugal. Project LIFE04NAT/PT/000213, Sociedade Portuguesa Para o Estudo das Aves, Lisbon

Ratcliffe N, Pelembe T, White R (2008) Resolving the population status of Ascension frigatebird Fregata aquila using a 'virtual ecologist' model. Ibis 150:300-306

Ratcliffe N, Bell M, Pelembe T, Boyle D and others (2010) The eradication of feral cats from Ascension Island and its subsequent recolonization by seabirds. Oryx 44:20-29

Rauzon MJ (2007) Island restoration: exploring the past, anticipating the future. Mar Ornithol 35:97-107

Rayner MJ, Hauber ME, Imber MJ, Stamp RK, Clout MN (2007) Spatial heterogeneity of mesopredator release within an oceanic island system. Proc Natl Acad Sci USA 104:20862-20865

Rayner MJ, Hauber ME, Clout MN, Seldon DS, Van Dijken S, Bury S, Phillips RA (2008) Foraging ecology of the Cook's petrel Pterodroma cookii during the austral breeding season: a comparison of its two populations. Mar Ecol Prog Ser 370:271-284
Regehr HM, Montevecchi WA (1997) Interactive effects of food shortage and predation on breeding failure of black-legged kittiwakes: indirect effects of fisheries activities and implications for indicator species. Mar Ecol Prog Ser 155:249-260

Reid PC, Colebrook JM, Matthews JBL, Aiken J, and the Continuous Plankton Recorder Team (2003) The Continuous Plankton Recorder: concepts and history, from Plankton Indicator to undulating recorders. Prog Oceanogr 58:117-173

Ribic CA, Chapman E, Fraser WR, Lawson GL, Wiebe PH (2008) Top predators in relation to bathymetry, ice and krill during austral winter in Marguerite Bay, Antarctica. Deep-Sea Res II 55:485-499

Richardson AJ, Schoeman DS (2004) Climate impacts on plankton ecosystems in the Northeast Atlantic. Science 305:1609-1612

> Riffaut L, McCoy KD, Tirard C, Friesen VL, Boulinier T (2005) Population genetics of the common guillemot Uria aalge in the North Atlantic: geographic impact of oil spills. Mar Ecol Prog Ser 291:263-273

> Roberts CM, McClean CJ, Veron JEN, Hawkins JP and others (2002) Marine biodiversity hotspots and conservation priorities for tropical reefs. Science 295:1280-1284

Roberts CM, Duncan RP, Wilson KJ (2007) Burrowing seabirds affect forest regeneration, Rangatira Island, Chatham Islands, New Zealand. NZ J Ecol 31:208-222

Robertson G, Moe E, Haugen R, Wienecke B (2003) How fast do demersal longlines sink? Fish Res 62:385-388

> Rolland V, Barbraud C, Weimerskirch H (2009) Assessing the impact of fisheries, climate and disease on the dynamics of the Indian yellow-nosed albatross. Biol Conserv 142:1084-1095

Ruffino L, Bourgeois K, Vidal E, Duhem C and others (2009) Invasive rats and seabirds after 2,000 years of an unwanted coexistence on Mediterranean islands. Biol Invas 11:1631-1651

> Ruiz X, Gonzalez Solis J, Oro D, Jover L (1998) Body size variation in Audouin's Gulls Larus audouinii: a densitydependent effect? Ibis 140:431-438

Russell RW (1999) Comparative demography and life history tactics of seabirds: implications for conservation and marine monitoring. Am Fish Soc Symp 23:51-76

Ryan PG, Boix-Hinzen C (1999) Consistent male-biased seabird mortality in the Patagonian toothfish longline fishery. Auk 116:851-854

Ryan PG, Watkins BP (2008) Estimating seabird bycatch by fisheries and its impact on seabird populations. Anim Conserv 11:260-262

Sandvik H, Erikstad KE, Barrett R, Yoccoz G (2005) The effect of climate on adult survival in five species of North Atlantic seabirds. J Anim Ecol 74:817-831

Sandvik H, Coulson T, Sæther BE (2008) A latitudinal gradient in climatic effects on seabird demography: results from interspecific analyses. Glob Change Biol 14:1-11

> Sanz-Aguilar A, Tavecchia G, Pradel R, Minguez E, Oro D (2008) The cost of reproduction and experience-dependent vital rates in a small petrel. Ecology 89:3195-3203

Sanz-Aguilar A, Massa B, Lo Valvo F, Oro D, Minguez E, Tavecchia G (2009) Contrasting age-specific recruitment and survival at different spatial scales: a case study with the European storm-petrel. Ecography 32:637-646

Schipper J, Chanson JS, Chiozza F (2008) The status of the world's land and marine mammals: diversity, threat, and knowledge. Science 322:225-230 
Schlosser JA, Dubach JM, Garner TWJ, Araya B and others (2009) Evidence for gene flow differs from observed dispersal patterns in the Humboldt penguin, Spheniscus humboldti. Conserv Genet 10:839-849

Schneider DC, Harrison NM, Hunt GL (1987) Variation in the occurrence of marine birds at fronts in the Bering Sea. Cont Shelf Res 5:241-257

Scholander PF, Hock R, Walters V, Johnson F, Irving L (1950) Heat regulation in some Arctic and tropical mammals and birds. Biol Bull 99:237-258

Schreiber EA, Burger J (eds) (2002) Biology of marine birds. CRC Press LLC, Boca Raton, FL

> Schreiber RW, Schreiber EA (1984) Central Pacific seabirds and the El Nino southern oscillation: 1982 to 1983 perspectives. Science 225:713-716

Shaffer SA, Tremblay Y, Weimerskirch H, Scott D and others (2006) Migratory shearwaters integrate oceanic resources across the Pacific Ocean in an endless summer. Proc Natl Acad Sci USA 103:12799-12802

> Sherman K, Jones C, Sullivan L, Smith W, Berrien P, Ejsymont L (1981) Congruent shifts in sandeel abundance in western and eastern North Atlantic ecosystems. Nature 291:486-489

Skov H, Durinck J, Leopold MF, Tasker ML (2007) A quantitative method for evaluating the importance of marine areas for conservation of birds. Biol Conserv 136: 362-371

> Skov H, Humphreys E, Garthe S, Geitner K and others (2008) Application of habitat suitability modelling to tracking data of marine animals as a means of analyzing their feeding habitats. Ecol Model 212:504-512

Slater L, Byrd GV (2009) Status, trends, and patterns of covariation of breeding seabirds at St Lazaria Island, Southeast Alaska, 1994-2006. J Biogeogr 36:465-475

Solomon S, Qin D, Manning M, Chen Z and others (2007) Climate change 2007: the physical science basis. Contribution of Working Group I to the 4th assessment report of the Intergovernmental Panel on Climate Change. Cambridge University Press, Cambridge

Southwell C, Low M (2009) Black and white or shades of grey? Detectability of Adelie penguins during shipboard surveys in the Antarctic pack-ice. J Appl Ecol 46: 136-143

Spear LB, Ainley DG (1999) Migration routes of sooty shearwaters in the Pacific Ocean. Condor 101:205-218

Spear LB, Ballance LT, Ainley DG (2001) Response of seabirds to thermal boundaries in the tropical Pacific: the thermocline versus the Equatorial Front. Mar Ecol Prog Ser 219:275-289

Spear LB, Ainley DG, Walker WA (2007) Foraging dynamics of seabirds in the eastern tropical Pacific Ocean. Stud Avian Biol 35, Cooper Ornithological Society, Los Angeles, CA, p 1-99

Spendelow JA, Nichols JD, Nisbet ICT, Hays H and others (1995) Estimating annual survival and movement rates of adults within a metapopulation of roseate terns. Ecology 76:2415-2428

Springer AM, Estes JC, van Vliet GB, Williams TM and others (2003) Sequential megafaunal collapse in the North Pacific Ocean: an ongoing legacy of industrial whaling? Proc Natl Acad Sci USA 100:12223-12228

Stempniewicz L, Blachowiak-Samolyk K, Weslawski JM (2007) Impact of climate change on zooplankton communities, seabird populations and arctic terrestrial ecosystem - a scenario. Deep-Sea Res II 54:2934-2945
Stenhouse IJ, Robertson GJ, Montevecchi WA (2000) Herring gull Larus argentatus predation on Leach's stormpetrels Oceanodroma leucorhoa breeding on Great Island, Newfoundland. Atl Seabirds 2:35-44

Suryan RM, Dietrich KS, Melvin EF, Balogh GR, Sato F, Ozaki K (2007) Migratory routes of short-tailed albatrosses: use of exclusive economic zones of North Pacific Rim countries and spatial overlap with commercial fisheries in Alaska. Biol Conserv 137:450-460

Sutherland WJ, Norris K (2002) Behavioral models of population growth rates: implications for conservation and prediction Philos Trans R Soc B 357:1273-1284

Sutherland WJ, Armstrong-Brown S, Armsworth PR, Brereton T, and others (2006) The identification of 100 ecological questions of high policy relevance in the UK. J Appl Ecol 43:617-627

Sutherland WJ, Adams WM, Aronson RB, Aveling R, and others (2009) One hundred questions of importance to the conservation of global biological diversity. Conserv Biol 23:557-567

Sydeman WJ, Mills KL, Santora JA, Thompson SA and others (2009) Seabirds and climate in the California Current-a synthesis of change. CalCOFI Rep, Vol 50.http: //www.faralloninstitute.org/Publications/Sydeman_et_ al_2009.pdf

Tavecchia G, Pradel R, Genovart M, Oro D (2007) Densitydependent parameters and demographic equilibrium in open populations. Oikos 116:1481-1492

Tavecchia G, Mínguez E, de León A, Louzao M, Oro D (2008) Living close, doing differently: small-scale asynchrony in demographic parameters in two species of seabirds. Ecology 89:77-85

> Tavecchia G, Besbeas P, Coulson T, Morgan BJT, CluttonBrock TH (2009) Estimating population size and hidden demographic parameters with state-space modelling. Am Nat 173:722-733

Tew Kai E, Rossib V, Sudreb J, Weimerskirch H and others (2009) Top marine predators track Lagrangian coherent structures. Proc Natl Acad Sci USA 106:8245-8250

Thaxter CB, Wanless S, Daunt F, Harris MP and others (2010) Influence of wing loading on trade-off between pursuit-diving and flight in common guillemots and razorbills. J Exp Biol 213:1018-1025

Thomas DW, Bourgault P, Shipley B, Perret P, Blondel J (2010) Context-dependent changes in the weighting of environmental cues that initiate breeding in a temperate passerine, the Corsican blue tit (Cyanistes caeruleus). Auk 127:129-139

Thompson PM (2006) Identifying drivers of change; did fisheries play a role in the spread of North Atlantic fulmars? In: Boyd IA, Wanless S, Camphuysen CJ (eds) Management of marine ecosystems: monitoring change in upper trophic levels. Cambridge Univeristy Press, Cambridge, p 143-156

- Thompson DR, Furness RW, Lewis SA (1995) Diets and longterm changes in $\delta^{15} \mathrm{~N}$ and $\delta^{13} \mathrm{C}$ values in northern fulmars Fulmarus glacialis from two northeast Atlantic colonies. Mar Ecol Prog Ser 125:3-11

Tremblay Y, Bertrand S, Henry RW, Kappes MA, Costa DP, Shaffer SA (2009) Analytical approaches to investigating seabirdenvironment interactions: a review. Mar Ecol Prog Ser 391:153-163

> Tuck GN, Polacheck T, Croxall JP, Weimerskirch H (2001) Modelling the impact of fishery by-catches on albatross populations. J Appl Ecol 38:1182-1196 
Underhill L (2007) A brief history of penguin oiling in South African waters. Avian Demography Union. http://web. uct.ac.za/depts/stats/adu/oilspill/oilhist.htm

van Bekkum M, Sagar PM, Stahl JC, Chambers GK (2006) Natal philopatry does not lead to population genetic differentiation in Buller's albatros (Thalassarche bulleri bulleri). Mol Ecol 15:73-79

- Van der Wal R, Truscott AM, Pearce ISK, Cole L, Harris MP, Wanless S (2008) Multiple anthropogenic changes cause biodiversity loss through plant invasion. Glob Change Biol 14:1428-1436

Veit RR, Montevecchi, WA (2006) The influences of climate change on marine birds. Acta Zool Sin 52: S165-S168

> Velando A, Munilla I, Leyenda PM (2005a) Short-term indirect effects of the 'Prestige' oil spill on European shags: changes in availability of prey. Mar Ecol Prog Ser 302: 263-274

Velando A, Alvarez D, Mouriño J, Arcos F, Barros A (2005b) Population trends and reproductive success of the European shag Phalacrocorax aristotelis on the Iberian Peninsula following the Prestige oil spill. J Ornithol 146: 116-120

> Veran S, Gimenez O, Flint E, Kendall WL, Doherty PF, Lebreton JD (2007) Quantifying the impact of longline fisheries on adult survival in the black-footed albatross. J Appl Ecol 44:942-952

Votier SC, Furness RW, Bearhop S, Crane JE and others (2004) Changes in fisheries discard rates and seabird communities. Nature 427:727-730

> Votier SC, Hatchwell BJ, Beckerman A, McCleery RH and others (2005) Oil pollution and climate have widescale impacts on seabird demographics. Ecol Lett 8: 1157-1164

Votier SC, Bearhop S, Fyfe R, Furness RW (2008a) Temporal and spatial variation in the diet of a marine top predator-links with commercial fisheries. Mar Ecol Prog Ser 367:223-232

> Votier SC, Birkhead TR, Oro D, Trinder M and others (2008b) Recruitment and survival of immature seabirds in relation to oil spills and climate variability. J Anim Ecol 77:974-983

> Votier SC, Bearhop S, Witt MJ, Inger R, Thompson D, Newton $J$ (2010) Individual responses of seabirds to commercial fisheries revealed using GPS tracking, stable isotopes and vessel monitoring systems. J Appl Ecol 47: 487-497

> Wahl TR, Ainley DG, Benedict AH, DeGange AR (1989) Associations between seabirds and water masses in the northern Pacific Ocean in summer. Mar Biol 103:1-11

> Wakefield ED, Phillips RA, Matthiopoulos J (2009) Quantifying habitat use and preferences of pelagic seabirds using individual movement data: a review. Mar Ecol Prog Ser 391:165-182

Wanless RM, Ryan PG, Altwegg R, Angel A, Cooper J, Cuthbert R, Hilton GM (2009) From both sides: dire demographic consequences of carnivorous mice and longlining for the Critically Endangered Tristan albatross on Gough Island. Biol Conserv 142:1710-1718

Watermeyer KE, Shannon LJ, Griffiths CL (2008a) Changes in the trophic structure of the southern Benguela before and after the onset of industrial fishing. Afr J Mar Sci 30: 351-382

> Watermeyer KE, Shannon LJ, Roux JP, Griffiths CL (2008b) Changes in the trophic structure of the northern
Benguela before and after the onset of industrial fishing. Afr J Mar Sci 30:383-403

Weimerskirch H (2002) Seabird demography and its relationship with the marine environment. In: Schreiber EA, Burger J (eds) Biology of marine birds. CRC Press, Boca Raton, Fl, p 115-135

> Weimerskirch H (2004) Diseases threaten Southern Ocean albatrosses. Polar Biol 27:374-379

Weimerskirch H (2007) Are seabirds foraging for unpredictable resources? Deep-Sea Res II 54:211-223

Weimerskirch H, Jouventin P (1987) Population dynamics of the wandering Albatross, Diomedea exulans, of the Crozet Islands: causes and consequences of the population decline. Oikos 49:315-322

> Weimerskirch H, Wilson RP (1992) When do wandering albatrosses Diomedea exulans forage? Mar Ecol Prog Ser 86:297-300

Weimerskirch H, Jouventin P, Stahl JC (1986) Comparative ecology of six albatross species breeding on the Crozet Islands. Ibis 128:195-213

Weimerskirch H, Capdeville D, Duhamel G (2000) Factors affecting the number and mortality of seabirds attending trawlers and long-liners in the Kerguelen area. Polar Biol 23:236-249

> Weimerskirch H, Bonadonna F, Bailleul F, Mabille G, Dell'Omo G, Lipp HP (2002) GPS tracking of foraging albatrosses. Science 295:1259

> White EM, Wilson JC, Anthony RC (2006) Biotic indirect effects: a neglected concept in invasion biology. Divers Distrib 12:443-455

Whittam TS, Siegel-Causey D (1981) Species interactions and community structure in Alaskan seabird colonies. Ecology 62:1515-1524

Wiens JA (1996) Oil, seabirds, and science. Bioscience 46: 587-597

- Wiese FK, Robertson GJ (2004) Assessing seabird mortality from chronic oil discharges at sea. J Wildl Manag 68: $627-638$

Wilson UW (1991) Responses of 3 seabird species to El Niño events and other warm episodes on the Washington coast, 1979-1990. Condor 93:853-858

Wilson RP, Grémillet D, Syder J, Kierspel MAM and others (2002) Remote-sensing systems and seabirds: their use, abuse and potential for measuring marine environmental variables. Mar Ecol Prog Ser 228:241-261

> Wilson RP, Shepard ELC, Liebsch N (2008) Prying into the intimate details of animal lives: use of a daily diary on animals. Endang Species Res 4:123-137

Yoccoz NG, Nichols JD, Boulinier T (2001) Monitoring biodiversity in space and time: concepts, methods and designs. Trends Ecol Evol 16:446-453

Yodzis P (2001) Must top predators be culled for the sake of fisheries? Trends Ecol Evol 16:78-84

Yorio P (2009) Marine protected areas, spatial scales, and governance: implications for the conservation of breeding seabirds. Conserv Lett 2:171-179

Young HS, Shaffer SA, McCauley DJ, Foley DG, Dirzo R, Block BA (2010) Resource partitioning by species but not sex in sympatric boobies in the central Pacific Ocean. Mar Ecol Prog Ser 403:291-301

> Zador SG, Parrish JK, Punt AE (2009) Factors influencing subcolony colonization and persistence in a colonial seabird, the common murre Uria aalge. Mar Ecol Prog Ser 376:283-293

Submitted: July 12, 2010; Accepted: January 17, 2012

Proofs received from author(s): March 30, 2012 